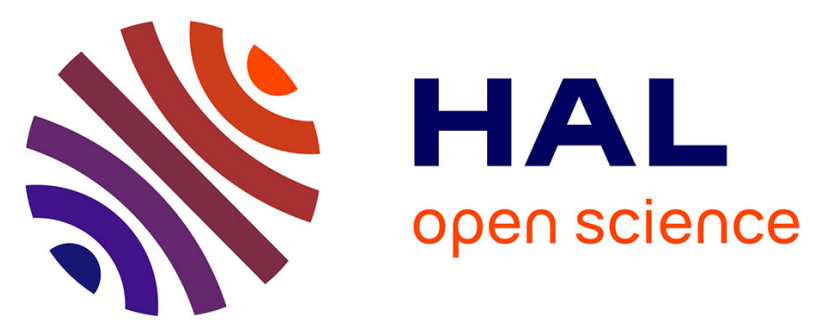

\title{
Early Cenomanian palynofloras and inferred resiniferous forests and vegetation types in Charentes (southwestern France)
}

Daniel Peyrot, Eduardo Barron, France Polette, David J. Batten, Didier Néraudeau

\section{To cite this version:}

Daniel Peyrot, Eduardo Barron, France Polette, David J. Batten, Didier Néraudeau. Early Cenomanian palynofloras and inferred resiniferous forests and vegetation types in Charentes (southwestern France). Cretaceous Research, 2019, 94, pp.168-189. 10.1016/j.cretres.2018.10.011 . insu-01897273

\section{HAL Id: insu-01897273 \\ https://hal-insu.archives-ouvertes.fr/insu-01897273}

Submitted on 17 Oct 2018

HAL is a multi-disciplinary open access archive for the deposit and dissemination of scientific research documents, whether they are published or not. The documents may come from teaching and research institutions in France or abroad, or from public or private research centers.
L'archive ouverte pluridisciplinaire HAL, est destinée au dépôt et à la diffusion de documents scientifiques de niveau recherche, publiés ou non, émanant des établissements d'enseignement et de recherche français ou étrangers, des laboratoires publics ou privés. 


\section{Accepted Manuscript}

Early Cenomanian palynofloras and inferred resiniferous forests and vegetation types in Charentes (southwestern France)

Daniel Peyrot, Eduardo Barrón, France Polette, David J. Batten, Didier Néraudeau

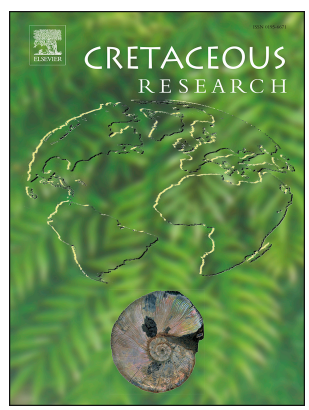

PII:

S0195-6671(18)30252-0

DOI:

10.1016/j.cretres.2018.10.011

Reference: YCRES 3988

To appear in: Cretaceous Research

Received Date: 21 June 2018

Revised Date: 19 September 2018

Accepted Date: 12 October 2018

Please cite this article as: Peyrot, D., Barrón, E., Polette, F., Batten, D.J., Néraudeau, D., Early Cenomanian palynofloras and inferred resiniferous forests and vegetation types in Charentes (southwestern France), Cretaceous Research (2018), doi: https://doi.org/10.1016/j.cretres.2018.10.011.

This is a PDF file of an unedited manuscript that has been accepted for publication. As a service to our customers we are providing this early version of the manuscript. The manuscript will undergo copyediting, typesetting, and review of the resulting proof before it is published in its final form. Please note that during the production process errors may be discovered which could affect the content, and all legal disclaimers that apply to the journal pertain. 


\title{
Early Cenomanian palynofloras and inferred resiniferous forests and vegetation types in Charentes (southwestern France).
}

\author{
Daniel Peyrot ${ }^{1 *}$, Eduardo Barrón ${ }^{2}$, France Polette ${ }^{3}$, David J. Batten ${ }^{4}$, Didier Néraudeau ${ }^{3}$ \\ ${ }^{1}$ School of Earth and Environment, University of Western Australia. 6101 Crawley, Western Australia. \\ daniel.peyrot@uwa.edu.au, *corresponding autor. \\ ${ }^{2}$ Museo Geominero, Instituto Geológico y Minero de España, Ríos Rosas 23, 28003 Madrid, Spain. \\ ${ }^{3}$ CNRS UMR 6118 Géosciences, Université de Rennes 1, Campus de Beaulieu, avenue du Général Leclerc, 35042 \\ Rennes, France \\ ${ }^{4}$ School of Earth, Atmospheric and Environmental Sciences, University of Manchester, Oxford Road, Manchester \\ M13 9PL, UK.
}

\begin{abstract}
A palynological analysis of 45 samples from six mid-Cretaceous amber-bearing outcrops from Charentes has been carried out. A total of 227 taxa have been recorded in the studied palynofloras. The palynological evidence suggests an early Cenomanian age for the assemblages. The heterogeneous compositions of the palynofloral assemblages indicate the existence of different coastal depositional settings with a variable but usually weak marine influence. The local vegetation was subdivided in various types including herbaceous formations integrating ferns and eudicots which may have colonised frequently-disturbed, fluvial, open environments and xeric arboreal communities dominated by Cheirolepidiaceae and probably integrating drought- and/or salt-tolerant angiosperms and ferns (Anemiaceae and Gleicheniaceae) and other gymnosperms (Araucariaceae, Ginkgoales and scarce Cycadales and Gnetales). The existence of riparian and freshwater wetland communities integrating taxodioids, aquatic and/or hygrophilous angiosperms, ferns, lycopods, mosses and clubmosses is proposed. Coastal/?lagoonal counterparts including plants tolerant to periodical floods by saline or brackish waters is suggested by palynological evidence. Conifer forests mainly integrating Pinaceae and Podocarpaceae in raised hinterlands may also be interpreted on the basis of taphonomical considerations. The wide variety of depositional settings inferred by the palynological data support enhanced transport capabilities for amber and/or a widespread occurrence of producers in local vegetation during the early Cenomanian.
\end{abstract}

\section{- Introduction}

The Cretaceous is characterized by a period of intense biotic turnover called the "Cretaceous Terrestrial Revolution", which saw a radiation of flora and fauna with modern characteristics (Lloyd et al., 2008). During this time, flowering plants assumed a dominant position in most ecosystems (Lidgard and Crane, 1990; Boyce et al., 2009; Friis et al., 2011; Herendeen et al., 2017). The changes in the three-dimensional architecture of the vegetation, probably triggered by 
previously underestimated high variability of climatic parameters (Berner, 2003; Keller et al., 2011; Littler et al., 2011; Fiedrich et al., 2012; Hay and Floegel, 2012), affected trophic networks and faunal clades (Labandeira, 2006; Kergoat et al., 2014; Peris et al., 2017) and irreversibly altered the composition of the overall terrestrial ecosystems (Meredith et al., 2011).

During the mid-Cretaceous, the Charentes area of southwestern France was part of a series of emerged lands located in the Laurasian Euro-Sinian phytogeographic province (Vakhrameev, 1991). Assemblages of plant macro-remains recovered from several outcrops suggest the existence of tropical forests with diverse ferns, conifers, Ginkgoales, Cycadales and angiosperms (Perrichot, 2003; Gomez et al., 2004; Moreau et al., 2017). These forests were characterized by a high production of resin, now occurring abundantly fossilized as amber, the paleontological content of which has been profusely documented during the past 15 years (Néraudeau et al., 2002, 2003, 2008, 2009).

However, while fairly well-known from Cenomanian outcrops of neighbouring areas (Azéma and Ters, 1971; Azéma et al., 1972, 1990; Néraudeau et al., 2017), the palynofloras have only been the subject of a few, partial or preliminary appraisals in Charentes (Deák and Combaz, 1967; Azéma et al., 1972; Azéma et al., 1990; Moreau, 1993a-c; Meunier et al., 1999; Néraudeau et al., 2002, 2008; Dejax and Masure, 2005; Peyrot et al., 2005; Batten et al., 2010). Altogether, 239 species of miospores and megaspores, many putatively produced by coastal vegetation have been recorded so far, along with 29 aquatic palynomorphs mostly represented by marginal marine dinoflagellate cysts (dinocysts).

The present paper reports a comprehensive study of the palynological content of six lower Cenomanian amber-bearing deposits from Charentes. It aims to (1) indicate the biostratigraphic significance of the components constituting the assemblages recovered, (2) reconstruct the corresponding source vegetation, and (3) provide a comparison of the palynofloras with contemporaneous palynological successions from Western Europe and North America. The present study is the first to describe the palynological assemblages of an entire array of amberbearing mid-Cretaceous outcrops in France. 


\section{- Geological settings}

Mid-Cretaceous successions crop out extensively in the northwestern part of the Aquitaine Basin (Fig. 1) where they reach an average thickness of $50 \mathrm{~m}$ (Moreau, 1993a-c). The studied outcrops consist of siliciclastic series and bioclastic limestones including amber-bearing strata and highly diverse macrofloral and macrofaunal assemblages (Néraudeau et al., 1997, 2002, 2003, 2008; Perichot et al., 2007; Vullo et al., 2003, 2005, 2007a-b; Gomez et al., 2004).

Moreau (1993a-c) and Néraudeau et al. (1997, 2002, 2005) divided the Albian-Cenomanian transition into a lower lithological unit $\mathrm{A}$, dominated by fine to coarse sandstones including alternations of clay, and an upper unit B corresponding to bioclastic limestones characterized by an abundance of oysters (Ceratostreon, Rastellum, Rhynchostreon) and rudists (Ichthyosarcolites, Sphaerulites), diverse vertebrate microremains (e.g. the squamate Simoliophis rochebrunei and the shark Carcharias amonensis) and large benthic foraminifers (mainly Orbitolina plana), indicating an age not older than early Cenomanian.

Unit A has been further divided into a subunit A1, dated as probable latest Albian (Dejax and Masure, 2005), or earliest Cenomanian (Néraudeau et al., 2008), according to pollen, spore and dinocyst assemblages, and a subunit A2, dated as Cenomanian on ostracod evidence (Colin, 1974; Damotte et al., 1981; Moreau, 1993a-c). The subunit A1 contains abundant lignite lenses and amber accumulations, but with few plant macro-remains (Moreau et al., 2017), and is characterized by large-scale cross-bedding, including heterometric coarse sand levels. The subunit A2 consists in fine-grained sands, without large-scale cross bedding, and several laminated clay levels, locally very thick $(>4 \mathrm{~m})$ and bearing fossil plants with exquisite preservation (Colin, 1974; Damotte et al., 1981; Moreau, 1993a-c; Moreau et al., 2017; Néraudeau et al., 2005).

The overlying unit B characterizes the first calcareous marine Cenomanian deposits, dated by foraminifers, ostracods and several macro-invertebrates (echinoids, oysters, rudists). The unit has been further divided into three subunits: a lower subunit B1 consisting of shallow marine bioclastic limestones, rich in small oysters (e.g. Rhynchostreon suborbiculatum var. minor), large benthic foraminifers (e.g. Orbitolina plana), and a first episode of large rudists (e.g. 
Ichthyosarcolites triangularis and Sphaerulites foliaceus) (Moreau, 1993a; Vullo et al., 2003); a middle subunit B2 corresponding to coastal and poorly oxygenated glauconitic unconsolidated sands and clays, poor in invertebrate remains but locally very rich in fish, crocodilian or dinosaur teeth and lagoonal squamate vertebrae (e.g. Simoliophis rochebrunei) (Moreau, 1993b; Vullo et al., 2005, 2007a,b); an upper carbonate subunit B3 corresponding in Charentes to the main Cenomanian episode with large non-reefal rudists such as Ichthyosarcolites triangularis and Sphaerulites foliaceus and including at its top a few intercalations of marls with organisms from relatively deep platform environments (such as the echinoids Periaster elatus and Hyposalenia acanthoides, or the ammonites Pseudacanthoceras pseudorevenieri) (Néraudeau and Moreau, 1989; Néraudeau et al., 1997).

The palynological analyses were carried out on assemblages recovered from six outcrops herein referred to as Archingeay-Les Nouillers, Les Renardières, Fouras, Aix Island (Bois-Joli), La Buzinie and Cadeuil, located in the northeastern and southwestern parts of the Saintes Syncline, respectively (Fig. 1). The outcrops constitute, together with a few localities in Spain, the oldest European deposits that include amber with bio-inclusions.

\section{- $\quad$ Archingeay-Les Nouillers succession}

The Archingeay-Les Nouillers succession comprises a mainly siliciclastic succession overlying upper Jurassic dolostones and marly limestones that crop out in two sand quarries (Fig. 2A). At the time of the sampling, subsunit A2 was still exposed and consisted of interbedded fine-to medium-grained sands $2.5 \mathrm{~m}$ thick displaying low angle, tabular (a1sm1) and hummocky crossbedding (A1sm2), mud drapes with occasional flaser and lenticular laminations including detrital plant fragments. The middle part of the succession was characterized by a section $4-5 \mathrm{~m}$ thick of massive, medium- to coarse-grained, unconsolidated sands (A1sm3) underlying bioturbated, fined- to medium-grained, sandstones displaying symmetrical ripples and occasional mud drapes (A1sm4). A total of 16 samples (ARC-B, ARC-01 to ARC-15) were collected from the lower and middle part of the section. The upper part of the succession consisted of a lenticular bed of clay, rich in plant cuticles that varied markedly in thickness laterally, reaching a maximum of 2 
$m$ in the north-northeast of the outcrop area (A2b). Ten samples (ARC-AR01 to ARC-ART) were collected from this bed every $20 \mathrm{~cm}$.

\section{- $\quad$ Cadeuil succession}

The outcropping section consists of 10-15 $\mathrm{m}$ of fine- to medium-grained sand and clay alternations. The lower part of the succession, structureless and lacking fossils, is overlain by sands showing apparent cross-bedding interrupted by distinctive layers of clay bearing cuticles and small plant fragments (Fig. 2B). The upper part of the succession corresponding to $\mathrm{cm}-\mathrm{dm}$ thick clays intercalated with medium-grained sands has been correlated previously with lenticular bed $\mathrm{A} 2 \mathrm{~b}$ characterizing the upper part of the Archingeay-Les Nouillers section (Perrichot, 2003). A total of 10 samples (CA-01 to CA-10) were collected from the clay levels representing the middle and upper parts of the succession.

\section{- $\quad$ Les Renardières, Aix Island (Bois-Joli), Fouras, and La Buzinie successions}

The lower part of the Les Renardières succession (Fig. 2C) consists of partially covered amberbearing clays $(\mathrm{A} 1 \mathrm{~b})$ that are rich in plant fragments. This interval is overlain by tabular and massive sands (A2a), which did not yield any macrofossils and has not been sampled for palynology. Néraudeau et al. (2005) referred the basal clays of A1 from Les Renardières to the uppermost Albian, but since the study of Néraudeau (2008), the boundary between lowermost Cenomanian and putative uppermost Albian in the Charentes region is known to be marked by a hard conglomerate. Such a conglomerate was not encountered at Les Renardières where the quarry is not very deep. Consequently the base of the section is more likely to be earliest Cenomanian in age.

The lower part of the succession on Aix Island (Bois-Joli) (Fig. 2E) consists of a $0.5 \mathrm{~m}$-thick fine- to medium-grained sandstone with a prevalent clay matrix including amber inclusions and plant fragments, rare vertebrate remains and oysters (B1a). The middle part of the section consists of a series of bioclastic sandstones containing relatively rich marine invertebrate faunal 
assemblages (B1b-B1e) and low angle cross-bedding (B1d). The overlying unit (B2a) corresponds to glauconitic clays and sandstones with oysters (Rhynchostreon suborbiculatum) including lenticular accumulations of plant megafossils and amber.

The lower part of the succession at Fouras (Fig. 2D) can be differentiated into a rudist-rich limestone (with Ichthyosarcolites triangularis) assigned to subunit B1 and overlying grey laminated clays including plant cuticles and debris (subunit B2a). The middle part of the succession consists of a nodular sandstone of variable thickness, overlain by glauconitic sand and clay including lenticular accumulations of vertebrate macrofossils (dinosaurs, turtles), amber and plant megadebris, some encrusted by pyritized brackish oysters such as Striostrea sp. (B2b/c). This bed has been interpreted to represent a tempestite or storm-induced deposit (Néraudeau et al., 2003). The upper part of the section comprises $8 \mathrm{~m}$ of glauconitic sand and clay alternations including marine oyster accumulations (Rhynchostreon suborbiculatum) and sometimes wellpreserved plant remains. Only the lower part of the succession (B2a) has been sampled for palynology.

The lower Cenomanian coastal deposits of La Buzinie directly overlie Kimmeridgian limestones, thus forming an important discordant palaeotopography (Fig. 2F). The A2 subunit is sporadically visible as lenticular dark clays and underlies the clastic limestones of unit B1. The base of B2 is composed of sandstones, underlying cross-bedded glauconitic sands with sandstones and argillaceous intercalations. The upper part of the subunit is represented by approximately $1 \mathrm{~m}$ of dark clays (not entirely represented on Fig. 2F). Two clayey samples (QPR3684 and QPR3677) were recovered from the A2 and B2 clays, but only the latter has been proven productive.

\section{- Material and methods}

Palynological analyses of 45 samples from six mid-Cretaceous amber-bearing outcrops in Charentes (supplementary data 2) have been carried out in order to infer the nature and age of their depositional settings and reconstruct their neighbouring and more distant vegetation. Palynofloral residues were obtained in the laboratories of Micropalaeontology of the Department of Palaeontology of the Universidad Complutense de Madrid and Aberystwyth University using 
standard techniques based on acid digestion with $\mathrm{HCl}$ and HF (Batten, 1999; Traverse, 2007). Residues were then concentrated by sieving through different mesh sizes (500 and $250 \mu \mathrm{m}$ in order to discard larger organic remains and $10 \mu \mathrm{m}$ to clear fine organic particles and insoluble minerals), and mounted in glycerine jelly on glass slides. The palynological samples were examined at the Geological Survey of Spain (IGME) using an Olympus BX51 compound microscope equipped with a Color View IIIu Camera and The University of Western Australia using a Nikon Eclipse Ni-U with interference contrast capabilities coupled with a Nikon DS-Fi2 camera. Some 500-1100 palynomorphs were identified per sample in order to record rare species.

Our palaeoenvironmental and biostratigraphic inferences were based on careful comparison of the percentage diagrams of different samples and outcrops obtained with Tilia and TGView 2.0.2 software (Grimm, 1992, 2004). The palynofloral assemblages were also compared with data from contemporaneous successions in Spain, Portugal, England and the United States. Macroand microfossil taxa cited in the text and/or recorded were grouped into botanical groups following various sources (Abbink et al., 2004; Peyrot et al., 2007; Friis et al., 2011; Doyle and Endress, 2014): these are listed in Appendix 1 (Supplementary data). Where botanical attributions had a limited resolution, broad (polyphyletic) groups were created. For example, monosulcate pollen grains with non-discriminative morphologies were merged in the composite group Ginkgoales/Cycadales/Bennettitales. The detailed coutings are provided as supplementary data.

\section{- Results}

Palynological recovery was usually good: $91 \%$ (41 out of 45) of the processed samples yielded a diverse palynomorph assemblage. The majority of the palynomorphs presented a relatively homogeneous light colour suggesting low thermal maturation (e.g. Traverse, 2007).

The assemblages from Cadeuil, Archingeay-Les Nouillers, Aix Island (Bois-Joli), Fouras, La Buzinie and Les Renardières yielded more than 200 types of palynomorphs (Appendices 1 and 2), mainly consisting of dinocysts (33 taxa identified), prasinophytes (3 taxa), acritarchs (5 taxa), 
freshwater algae (6 taxa), bryophyte and pteridophyte spores (63 taxa), and gymnosperm (26 taxa) and angiosperm pollen grains (60 taxa). Abundance data are represented in figs 3 and 4 and the most biostratigraphically and palaeoenvironmentally significant palynomorphs are illustrated in figs. 5-11. The most frequently occurring dinocysts are Epelidosphaeridia spinosa (Fig. 5A; present in $85 \%$ of the recovered assemblages), Subtilisphaera spp. (Fig. 5C; 70\%), Spiniferites ramosus (Fig. 5G; 53\%) and Cyclonephelium spp. (30\%) including Circulodinium distinctum (Fig. 5J). Freshwater algae are mainly represented by Schizosporis reticulatus, Ovoidites parvus and Tetraporina spp., but never numerically significant. The sporadic presence of palynofloral elements interpreted as Triassic reworking (Fig. 6, figs. 1-9) was noted in most of the samples. These include various species of Aratrisporites (Figs. 6A-B), Protodiploxypinus (Figs. 6G-H) and, more questionably, Zebrasporites (Figs. 6C-F). The preservation varied from poor to fairly good with a high number of palynomorphs (mainly terrestrial) presenting signs of physical and chemical damages including abrasion, tearings and oxidations (Figs. 7O, R, T).

Apart from those from Les Renardières and Aix Island (Bois-Joli) LB2, all of the terrestrial assemblages are dominated by taxonomically restricted gymnosperm associations (Fig. 3), and in all of the samples studied, angiosperm pollen comprise only a minor part of the assemblages. The most common spores encountered include Gleicheniidites senonicus, Ornamentifera spp., Plicifera spp. (Figs. 7P-Q), Cyathidites australis (Fig. 7J), Camarozonosporites ambigens (Fig. 8A), Cicatricosisporites spp. (Figs. 8G-H). Gymnosperm pollen grains are mainly represented by Classopollis spp., Classopollis sp. cf. C. major (Fig. 9K), Balmeiopsis limbata (Fig. 9G), Afropollis spp. (Fig. 9U), Taxodiaceaepollenites hiatus (Fig. 9I), along with various bisaccates such as Pinuspollenites spp. and Parvisaccites radiatus (Fig. 9L). Commonly recorded angiosperms include Clavatipollenites minutus (Fig. 10B), Dichastopollenites reticulatus (Fig. 10M), Transitoripollis anulisulcatus (Figs. 10F-G), and numerous species characterized by tricolpate or derived apertures (Figs. 11A-X).

\section{- $\quad$ Cadeuil succession}


The palynological succession can be divided into two parts. The lower of these, covering the interval between samples CA-01 and CA-04 is characterized by moderate to high numbers of marine palynomorphs (mainly dinocysts), dominant gymnosperms and decreasing-upward proportions of spores. The upper part (from sample CA-05 upwards) is characterized by a muchreduced proportion of marine palynomorphs, dominant to sub-dominant gymnosperms and increasing numbers of spores (Fig. 4A). The most common spores encountered throughout the succession belong to the Gleicheniaceae and Cyatheaceae/Dicksoniaceae/Dipteridaceae (Appendix 2; Figs. 3, 4A), whereas the gymnospermous component is mostly represented by Cupressaceae s. l. (i.e. including taxodioids) identified as Inaperturopollenites dubius and $T$. hiatus and, to a minor extent, by Classopollis, produced by Cheirolepidiaceae (Figs. 3-4A).

Pollen grains attributed to the Araucariaceae and Gnetales/Erdtmanithecales and spores of lycophytes follow the same abundance pattern (Figs. 3, 4A). It is noteworthy that the upper levels of the Cadeuil succession yielded significant percentages of Ginkgoales/Cycadales/Bennettitales and angiosperms. The latter are dominated by monocolpate grains attributed to the Chloranthaceae and probable monocots including Pennipollis reticulatus (Fig. 10Q), Pennipollis sp. cf. P. peroreticulatus (Fig. 10R), and Clavatipollenites spp. (Figs. 10B-D). Pollen with eudicot affinities are moderately diverse, and include Tricolpites němejci (Figs. 11A-B), Phimopollenites pseudocheros (Fig. 11F), Penetetrapites mollis (Fig. 11G) and Foveotricolporites callosus (Fig. 11V).

\section{- $\quad$ Archingeay-Les Nouillers succession}

The palynological succession appears relatively homogeneous with subordinate marine elements. Gymnosperm pollen grains are largely dominant and constitute three-quarters of the assemblages. In contrast with the Cadeuil succession, taxodioids, although dominant, have been recorded in slightly lower numbers (Figs. 3, 4B), whereas representatives of the Cheirolepidiaceae are a more conspicuous component of the assemblages. Spores of Anemiaceae, such as Appendicisporites, appear to be significantly more diverse and abundant in Archingeay-Les Nouillers than in Cadeuil, this increase being paralleled by an opposite trend in representation of the Cyatheaceae/Dicksoniaceae/Dipteridaceae. The increase in abundance in 
Anemiaceae is also reflected by a high taxonomic diversity, which is particularly well represented by the genus Appendicisporites (Figs. 8I-P).

The relative abundance of pollen attributed to taxodioids, Araucariaceae, and spores of Gleicheniaceae seems negatively correlated with that of the Cheirolepidiaceae (Fig. 4B). While slightly less abundant, the taxonomic composition of the angiosperms is very similar to that of Cadeuil. Mono-aperturate grains attributed to the Chloranthaceae and probable monocots are more diverse in the lower part of the succession (samples ARC-6 and ARC-7). Pollen with tricolpate or derived morphologies showed a similar but less-marked evolution of diversity and include Tricolpites němejcii (Figs. 11A-B), Striatopollis spp. (Fig. 11E) and Nyssapollenites spp. (Figs. 11N, Q-R). Polyporate grains (Figs. 11H-K) were encountered in the lowermost sample of the succession and were more frequently recorded up-section. Their presence together with obligate tetrads such as Artiopollis indivisus (Fig. 11W) and Senectotetradites grossus (Fig. 11X) are considered to be biostratigraphically significant (see discussion).

Palynomorphs considered to be reworked were slightly more common in this succession, usually accounting for around $1 \%$ of the total assemblages (Fig. 4B). The level ARC-AR3 yielded the highest numbers of reworked palynomorphs of all of the Charentes samples examined.

- $\quad$ Les Renardières, Aix Island (Bois-Joli), Fouras, and La Buzinie outcrops

The smaller number of samples taken from these outcrops yielded distinctive palynological assemblages. In Les Renardières (Subunit A1b), marine palynomorphs represent c. 5\% of the total assemblage, dinocysts being the most diverse group with nine species recorded. Miospores constitute half of the palynofloral assemblage and are represented by diverse Gleicheniaceae (Clavifera triplex, Gleicheniidites senonicus, Plicifera spp.), frequent Cyatheaceae/Dicksoniaceae/Dipteridaceae such as Cyathidites australis,-and various taxa attributed to Camarozonosporites (Figs. 8A-C). Gymnosperms (c. 44\%) are mainly represented by Classopollis spp. and Inaperturopollenites dubius. Angiosperms constitute less than $2 \%$ of the assemblages and are represented by monosulcate grains and a single tricolpate pollen grain (Tricolpites sp. cf. T. vulgaris). 
The two levels from Aix Island (Bois-Joli) showed radically different assemblages. The palynoflora recovered from subunit B1b (LB1) contains the highest proportions of dinocysts of all the Charentes samples (c. $58 \%$ of palynofloral components). This assemblage also includes the largest number of bisaccate grains of all the assemblages studied (20\% of the total palynoflora of LB1, supplementary data), representing c. 55\% of the miospores (Fig. 3). In LB1, spores constitute one-third of the miospore association and are mainly attributable to the Anemiaceae, Gleicheniaceae and Cyatheaceae/Dicksoniaceae/Dipteridaceae (Fig. 3). Angiosperm pollen grains constitute c. $1 \%$ of the terrestrial palynoflora, and are a minor part of the assemblage. Conversely, the assemblage recovered from subunit B2a (LB2) is characterized by a very low proportion of dinocysts $(<2 \%$ of the total number of palynomorphs, supplementary data) and the highest number of spores of the studied samples (c. $87 \%$ of the total number of palynomorphs, supplementary data). The latter include a lower proportion of representatives of the Anemiaceae than in the underlying unit and a higher number of spores attributable to the Gleicheniaceae. Furthermore, LB2 is the only palynological assemblage from Charentes that is characterized by a large proportion of lycophytes (Fig. 3). Gymnosperms only reach c. 10\% of the spore/pollen association and are mainly represented by pollen referable to the Cupressaceae and Cheirolepidiaceae. Angiosperms represent less than $2 \%$ of the miospores and therefore constitute only a minor part of the LB2 assemblage.

The only sample examined from Subunit B2 of the Fouras outcrop yielded an assemblage in which dinocysts constitute c. $9 \%$ of the total number of palynomorphs (supplementary data). Accounting for more than $50 \%$ of the miospore association, gymnosperms are represented by subdominant pollen attributable to the Cupressaceae and Cheirolepidiaceae. Spores amount to c. $42 \%$ of the continental palynomorph association, gleicheniaceous specimens being particularly abundant. In common with the palynofloras from Aix Island (Bois-Joli) and Les Renardières, angiosperms are not numerically significant in Fouras (Fig. 3).

The only productive sample recovered from subunit B2 at La Buzinie yielded an assemblage, composed of 68 species, taxonomically dominated by bryophyte and fern spores ( 34 species). In terms of abundance, they represent $39 \%$ of the terrestrial palynomorphs and $34 \%$ of the whole 
assemblage (Fig. 3). Gleicheniidites senonicus is the most abundant taxon of the spore association. Anemiaceae represent the most diverse group with 14 species attributed to Appendicisporites, Cicatricosisporites, Ischyosporites and Distaltriangulisporites (Appendices 1 and 2). Gymnosperms are the most abundant palynomorphs, representing $56 \%$ of the terrestrial palynoflora and $47 \%$ of the entire assemblage. They are less than twice as diverse than the spores (16 species), and are mostly represented by the cheirolepid Classopollis, along with numerous araucariacean and cupressaceous pollen referred to Balmeiopsis, Araucariacites, and Inaperturopollenites. Only a few bisaccates were recorded. As for the previous assemblages, angioperm pollen grains are less common and diverse, representing only $5 \%$ of the assemblage with eight species. They are dominated by the monocolpate species Pennipollis reticulatus.

Fourteen per cent of the palynomorphs recorded are dinocysts, represented by five species, the most common form of which is Spiniferites ramosus. A few freshwater algae, acritarchs, and reworked palynomorphs have also been encountered (Appendices 1 and 2). Added to that, a small assemblage of megaspores has been recovered and documented by Batten et al. (2010).

\section{- Discussion}

\section{- Biostratigraphy}

In Cadeuil, the presence of Palaeohystrichophora infusorioides indicates an age not older than latest Albian (Costa and Davey, 1992; Foucher and Monteil, 1998) while the record of Epelidosphaeridia spinosa indicates an age not younger than late early Cenomanian (Costa and Davey, 1992). The latest Albian-early Cenomanian interval given by dinocysts is also broadly supported by terrestrial palynomorphs. The presence of Cupuliferoidaepollenites parvulus and pollen grains with tricolporate apertures suggests an age not older than late Albian (Hochuli et al., 2006; Horikx et al., 2016). The distinction between the late Albian and the early Cenomanian on the basis of terrestrial palynomorphs is difficult and remains debated. The reference sections for the interval are from the Potomac Group, a unit widely outcropping in the Atlantic Coastal Plain, eastern United States. The upper part of the succession has been first described by Brenner (1963) who distinguished between a lower Albian Subzone IIA and a middle to upper Albian 
Subzone IIB. Doyle and Robbins (1977) restudied the original material and refined the zonation dividing the succession into three subzones assigning them a middle Albian-early Cenomanian age interval. The Potomac succession has been later recalibrated by Ward (1986), Doyle (1992), Hughes (1994) and Hochuli et al. (2006). More recently, Horikx et al. (2016) compared the palynoflora of São Julião, Portugal with the Potomac succession and suggested a late Albianearly Cenomanian age for the Subzone IIC on the basis of the absence of small tricolporate pollen grains with a triangular equatorial outline. Palynoflora from Charentes is interpreted to be NW European equivalent of the Subzone IIC of the Atlantic Coastal Plain of the United States.

Interestingly, the Portuguese assemblages are characterised by diverse zonosulcate pollen grains attributed to Dichastopollenites including D. dunveganensis. These forms, also well-represented in Charentes, are restricted to the late Albian in Portugal. The first appearance of $D$. dunveganensis during the middle Cenomanian in Canada suggests a stratigraphic distribution controlled by latitude (e.g. a diachronous record) and a biostratigraphic value more local than extra-regional. Conversely, the presence of a form identified as Nyssapollenites nigricolpus in one sample $(\mathrm{CA}-\mathrm{B}+4.5)$ suggests a younger age, the species not being recorded in strata older than Cenomanian in Africa (El-Beialy et al., 2010). A Cenomanian age is also supported by the fairly consistent presence of Tricolpites němejcii and Microreticulatisporites sacalii, which first occur in strata of that age in Europe and North America respectively (Hochuli et al., 2006; Ludvigson et al., 2010).

An early Cenomanian age is also provided and well-constrained by ostracod and foraminifer assemblages gathered from the underlying strata (upper part of subunit A1, Colin, 1974; Damotte et al., 1981) and overlying it (lower part of subunit B1, Moreau, 1993a-c), respectively. The presence of these marine markers in Charentes is important as it provides an external and independent calibration to refine the correlation of mid-latitude palynological successions of both sides of the Proto-North Atlantic.

The stratigraphic markers encountered in the samples from Cadeuil have also been recorded in the Archingeay-Les Nouillers succession. However, the presence of Cicatricosisporites crassiterminatus and more diverse angiosperm associations, including additional polyporate taxa (Bohemiperiporis spp., Cretacaeoiporites sp. 1), have been recorded from Archingeay-Les Nouillers. These records provide further evidence in support of a Cenomanian age (Pacltová, 
1968; Ludvigson et al., 2010). A palynological analysis was carried out on underlying strata (subunit A1), suggesting a latest Albian age of deposition (Dejax and Masure, 2005). However, this assignation was based on inconclusive evidence (i.e. absence of a biostratigrahic marker) from a small set of samples, and the authors may have undervalued the influence of facies.

The isolated samples collected from Fouras, Aix Island (Bois-Joli), Les Renardières, and La Buzinie yielded only a few taxa that have stratigraphic relevance. The presence of Epelidosphaeridia spinosa and Microreticulatisporites sacalii enables correlation of these samples with the successions from Cadeuil and Archingeay-Les Nouillers and are also concordant with an early Cenomanian age.

Some of the palynomorphs identified as reworked (Appendices 1 and 2), have rather long stratigraphic ranges covering the Triassic and, probably, the Lower Jurassic (Mädler, 1964; Morbey, 1975; Planderová, 1980; Batten and Koppelhus, 1996; Haas et al., 1997). The occurrence of Duplicisporites spp. and Protodiploxypinus spp. suggests reworking from Ladinian-Norian strata as these markers are restricted to this interval in Europe (Visscher and Brugman, 1981).

The absence of Jurassic elements in Charentes assemblages suggests reworking and transport from regional/remote source rather than local strata.

\section{- $\quad$ Palaeoenvironments}

\subsubsection{The significance of inaperturate pollen grains}

A distinctive feature of the palynofloras from Charentes is the high number of inaperturate pollen grains (Fig. 3) assigned to taxodioid conifers, including Perinopollenites halonatus (Fig. 9H), Inaperturopollenites dubius, the papillate Taxodiaceaepollenites hiatus (Fig. 9I), and specimens questionably referred to Sciadopityspollenites spp. (Fig. 9J). These conifers are now mainly distributed in warm- to cool-temperate latitudes of the Northern Hemisphere (Farjon, 2005) and include species with a high-water requirement such as the bald cypress (Taxodium distichum), 
the Moctezuma cypress (Taxodium mucronatum) and the Chinese swamp cypress (Glyptostrobus pensilis). These trees grow in swamp environments and on saturated soils and wetlands subjected to periodic flooding (Spackman et al., 1969; Willard, 2001; Farjon, 2005). Taxodioids represent a significant part of Aptian and Albian macrofloras of Central, and Western Europe, and the Atlantic coast of North America (Stockey et al., 2005). Accordingly, the high number of inaperturate pollen grains recorded in Charentes suggest the existence of conifer forests linked to freshwater wetlands and low-salinity back-swamp environments. The representation of the taxodioid pollen differs between outcrops (Fig. 3.A), suggesting derivation from a variety of relatively distinct depositional settings and vegetation types. Nearshore, wave- and tidallyinfluenced settings, however, may have supported other types of plants, more adapted to withstand higher salinity levels.

\subsubsection{The location of Classopollis-producers}

Classopollis spp. are frequently an important component of the palynofloras of Charentes (Fig. 3), but they rarely constitute the dominant element. This contrasts with the macrofloral assemblages in which remains of cheirolepids, such as leafy axes attributed to Frenelopsis alata or the ovuliferous scales Alvinia bohemica, constitute nearly always the main type of plant remains (Gomez et al., 2004, 2008). This difference may reflect a complex biostratinomic history in which many palynomorph types were transported over longer distances than macrofloral elements. Although palynomorphs represent diaspores ensuring the dispersal of plants, their vegetative fragments are usually fixed to a substrate (Spicer, 1991; Prentice, 1988). For this reason, palynofloras are generally regarded as representing a geographically broader picture of the vegetation than plant macrofossil assemblages (Birks and Birks, 1980).

In addition, abundances of Classopollis spp. vary significantly, as is relatively well exemplified in the Cadeuil or Archingeay-Les Nouillers successions (Figs. 4A, B). This suggests that their distribution is controlled by facies and possibly limited dispersal capabilities, a hypothesis that has been presented previously with reference to late Cenomanian marine assemblages from northern Spain in which cheirolepids constitute a subordinate component of palynofloras dominated by wind-transported Normapolles (Peyrot et al., 2011). Both palynological and 
macrofloral data support the presence of representatives of the Cheirolepidiaceae in the vegetation of Charentes during the early Late Cretaceous. This family has been associated with dry and/or saline environments for many years (e.g. Alvin, 1982; Vakhrameev, 1991). In 2008, Gomez et al. suggested the existence of mangrove and salt marsh vegetation with representatives of this family in Archingeay-Les Nouillers occupying the coastal region of Charentes during the Cenomanian. This hypothesis, previously suggested by Batten (1974), is appealing, and vegetation colonizing restricted lagoonal settings has also been documented in much older deposits (Taylor et al., 2009). Modern environments periodically flooded by marine or brackish waters are colonized by mangrove vegetation in tropical and subtropical latitudes. This coastal vegetation type shows a latitudinal distribution that is broadly similar to that of the coral reefs, and involves flowering plants such as Avicennia and Rhizophora, which have highly specialized organs (pneumatophores) to allow oxygen uptake. This type of morphological structure and/or other anatomical features that unequivocally indicate the presence of mid-Cretaceous cheirolepid mangrove communities in Charentes have yet to be discovered. It is likely, however, that cheirolepids colonised the driest environments in the vincinity of the depositional sites, forming the arboreal component of forest vegetation documented elsewhere in Western Europe (Diéguez et al., 2010).

\subsubsection{The importance of the flowering plants}

According to Lidgard and Crane (1990), the first floras where angiosperms assumed a dominant position developed during the latest Albian and Cenomanian. The presence of angiosperms in Charentes is characterized by palynofloras that include forms with diverse monocolpate and tricolpate or derived apertural morphologies. It is important to note that the insect pollination exhibited by many (if not most) representatives of the early flowering plants (Taylor and $\mathrm{Hu}$, 2010) may produce an underestimated signal of the corresponding producers in the palynological assemblages as entomophilous pollen grains are usually not produced in high quantity nor very well dispersed.

Obligate tetrads attributed to the Nelumbonaceae including Senectotetradites fenestralis and $S$. grossus (Fig. 11X) have been recorded herein. The record of these presumably aquatic 
angiosperms suggests the presence of back-swamps, ponds and small lakes close to the sites of deposition. Pollen grains attributed to the Chloranthaceae (Clavatipollenites spp., Asteropollis spp. and Hammenia fredericksburgensis) have been frequently recorded together with probable monocots in Charentes (Figs. 4A,B). The Chloranthaceae have a present-day distribution that is restricted to low- to mid-latitudes in south-eastern Asia, Indonesia, New Zealand, Madagascar and Central and South America. Modern representatives of the family are ecologically flexible and colonize wet, disturbed, dark or sunny habitats (Feild et al., 2004). Following such an 'actualistic' interpretation, angiosperms of the early Late Cretaceous in Charentes may have comprised aquatic and associated, frequently disturbed, hygrophilous communities. It is important to note that representatives of the Chloranthaceae probably had wider ecological requirements during the Cretaceous than today. For example Pseudoasterophyllites cretaceous, which has been recorded in macrofloral assemblages from Charentes and Bohemia (Kvaček et al., 2012, 2016), would be an early representative of the family with halophytic adaptations, unknown in modern Chloranthaceae.

The presence of flowering plants in other early Late Cretaceous plant communities of Charentes is supported by the highly diverse record of tricolpate or derived apertural morphologies and polyporate grains. These pollen grains were produced by eudicots that probably had heterogeneous ecological requirements. Macrofloral inventories carried out in the quarries of Archingeay-Les Nouillers, and elsewhere in Charentes included dominant cheirolepids and allies (Geinitzia, Glenrosa, Brachyphyllum), frequent representatives of Ginkgoales (Eretmophyllum, Nehvizdyella), but only rare angiosperms (Gomez et al., 2008; Moreau et al., 2014). These contrasting results between palyno- and macrofloras may be explained by preservation bias related to the composition of the remains: easily degraded herbaceous forms vs. durable schlerophyllous and woody matter. Selective preservation could explain the absence of certain families in the palynofloras. Macro-remains of the lauracean Eucalyptolaurus depreii have been identified in various sites in Charentes (Gomez et al., 2008; Coiffard et al., 2009; Moreau et al., 2017), but so far, no palynomorphs attributed to this family have been encountered in the study area. This is probably because their pollen are readily degraded. The presence of the Lauraceae in Charentes is likely to be associated with a wide range of habitats including calm freshwater swamps, ponds alongside stream channels, and/or brackish mudflats (Gomez et al., 2008; 
Coiffard et al., 2009). The wide array of depositional settings including fragments of Eucalyptolaurus depreii may be related to a broad physiologic tolerance, and an ability to colonize disturbed habitats. This species may constitute another example of early ' $r$-selected' angiosperms that are thought to be pioneer herbaceous, shrubs or small trees capable of colonizing frequently disturbed environments (Feild et al., 2004; Coiffard et al., 2006).

As a result, it is likely that angiosperms were invading different plant communities in Charentes, including aquatic, frequently disturbed and more stable hygrophilous and xerophilous associations. The true representation of flowering plants in the early Cenomanian vegetation of this region may be underestimated for morpho-functional (e.g. low production and dispersal of entomophilous pollen) and taphonomic (low preservation potential of presumed herbaceous parts) reasons.

\subsubsection{The significance of Gleicheniaceae, Anemiaceae and other spore-producers}

The high abundance and diversity of the Gleicheniaceae and Anemiaceae recorded in preliminary results (Peyrot et al., 2005) are confirmed by the present study. The ferns of these two families as well as representatives of the Matoniaceae are characteristic elements of both mid-Cretaceous macro- (Gleichenia, Anemia, Weichselia) and palynofloras (Gleicheniidites, Plicifera, Cicatricosisporites, Appendicisporites, Matonisporites, Dictyophyllidites) in Western Europe and North America (Vakhrameev, 1991). Of the three families, the Gleicheniaceae are particularly abundant and diverse in Central and Western Europe. In the Aptian-Cenomanian successions of the Lower Greensand and Selborne groups in southern England, spores of Gleicheniaceae constitute up to $52 \%$ of the palynoflora (Kemp, 1970). In Charentes, representatives of this family comprise an average of $15 \%$ of the terrestrial microflora, contrasting with the low numbers recorded in contemporaneous amber-bearing samples from Spain (Barrón et al., 2015). Modern Gleicheniaceae are tropical and subtropical ferns adapted to withstand drought conditions and may form dense thickets on disturbed open sites, including forest margins, savannas, dry forests and wetlands that occasionally dry out (Mehltreter et al., 2012). Their common occurrence in coarse-grained strata in association with matoniaceaeous ferns and sphenopsids (Batten, 1974; Vakhrameev, 1991) suggest that fossil representatives of 
the family had similar ecological requirements, and colonised frequently disturbed habitats such as river banks, sand bars and, potentially, xeric settings. In Archingeay-Les Nouillers (Figs. 3, 4B), representatives of the Gleicheniaceae are more abundant in palynological assemblages with lower numbers of tricolpate angiosperms. This may reflect an ecological succession in a fluvial environment, where plant communities with abundant gleicheniaceous ferns (disturbancedominated) alternated with those containing eudicots (community recovery). This dual model is, however, simplistic, a mixture of floral elements (mosses + ferns + angiosperms) was probably as prevalent during the Cretaceous as it is in modern vegetation.

The first record of Anemiaceae in the fossil record dates from the Middle Jurassic, the family presumably acquiring a nearly cosmopolitan distribution by the Early Cretaceous (Harris, 1961; Taylor et al., 2009). This family is most diverse in modern tropical areas of Australasia. Modern representatives thrive in open environments with well-drained soils low in nutrients (Tryon and Tryon, 1982; Mehltreter et al., 2012). Some species have adapted to tolerate partial desiccation (Proctor and Tuba, 2002). In contrast to contemporaneous amber-bearing strata in northern Spain (Barron et al., 2015; Rodriguez-Lopez et al., in press), assemblages from Charentes are characterized by containing a morphologically diverse range of Appendicisporites (eight species). This is quite unusual and has been previously recorded in late Albian palynofloras from the Muddy Sandstone of the Gulf Coast, USA (Ravn, 1995).

The spore-dominated assemblage from Aix Island (Bois-Joli, LB2) is very different from all of the other mid-Cretaceous palynofloras of Charentes (Fig. 3). The high spore content probably represents a very local vegetation. Being generally heavier than pollen grains, spores tend to be dispersed less widely, commonly being deposited close to the ferns and mosses that produce them (leptokurtic distribution sensu Ferguson, 1995). The elevated number of spores recorded in LB2 indicates the proximity of ferns to the sampling site, as evident in modern-day settings (Jacobson and Bradshaw, 1981) such as those characterizing Lake Tulane in Florida (Watts and Hansen, 1994).

\subsubsection{The significance of bisaccate grains and dinocysts in the Aix Island (Bois-Joli) outcrop}


The stratigraphically lowest palynological assemblage from Aix Island (Bois-Joli) (LB1, Fig. 2C) is characterized by containing numerous dinocysts and bisaccate grains (Fig. 3) including Parvisaccites radiatus (Fig. 9L). High proportions of dinocysts have been traditionally regarded as indicative of open marine depositional settings (Davey and Rogers, 1975; McCarthy and Mudie, 1998), whereas bisaccate pollen grains, owing to their aerodynamic characters, and abundant production by wind-pollinated Podocarpaceae and Pinaceae often represent the main palynological components of terrestrial vegetation in offshore settings (e.g. Mudie and McCarthy, 1994; McCarthy and Mudie, 2006). Accordingly, the high proportion of dinocysts and bisaccate grains suggest a relatively distal setting during the time of deposition. Marine influence is also clearly indicated by faunal assemblages recovered from the same interval, including selachians and turtles (Néraudeau et al., 2009). In this context, the LB1 palynofloral assemblage would be evidence of a regional rather than local vegetation. In Charentes, the abundance of macroremains of Podocarpaceae (Podocarpoxylon) is low (Neraudeau et al., 2003, 2008) except in Fouras, where representatives of this family represent one-quarter of the assemblage. This bi-modal distribution of macrofloral elements suggests the existence of different vegetation types in the study area with one including Podocarpaceae. These hypotheses are not mutually exclusive and the presence of these bisaccate producers in localized neighbouring areas and raised hinterlands may be postulated. In present-day and recent settings, Podocarpaceae constitute a significant component of middle-altitude "fairly dry" rainforests (Moss and Kershaw, 2000) and lowland swamps or river banks (Dacrydium spp.; Kershaw, 1976).

5.2.6. The megaspore assemblages of Charente and the role of their producers in the local vegetation

The megaspore assemblages described by Batten et al. (2010) include abundant Minerisporites and Paxillitriletes in association with Bacutriletes, Erlansonisporites, Molaspora and Ariadnaesporites. These megaspores, produced by Salviniales, Isoetales and other lycopsids growing near or in freshwater bodies (Batten et al. 1994; Batten and Collinson, 2001), give additional support to the presence of swamps or water-logged habitats suggested by some angiosperm (Nelumbonaceae and probably Chloranthaceae) and gymnosperm taxa (taxodioids) 
documented herein. Altogether, these results suggest the close proximity of wetland and backswamp communities composed of a putative arboreal stratum and a diverse understory including free-sporing plants and angiosperms.

\subsubsection{Reconstruction of vegetated areas in the early Late Cretaceous of Charentes}

The palynofloras recovered from the Charentes outcrops are not homogeneous. This reflects a diverse array of depositional settings and probably also indicates a variety of plant communities. The inferred vegetation types include (i) freshwater environments such as wetlands and backswamps with taxodioids, ferns and presumably aquatic and hygrophilous angiosperms, locally, dominated by spore-producers including lycophytes (LB2), (ii) frequently disturbed environments in which representatives of the Gleicheniaceae and other ferns, and angiosperms (Eucalyptolaurus depreii) occurred in varying proportions, (iii) xeric habitats dominated by cheirolepids, including some Ginkgoales and angiosperms with xeromorphic adaptations (Pseudoasterophyllites cretaceous), Anemiaceae, Matoniaceae and other drought-tolerant ferns and, probably, more local populations of Podocarpaceae and Araucariaceae (La Buzinie), (iv) coastal/?lagoonal communities comprising Classopollis-producers and (v) a raised (?mesic) hinterland inhabited by representatives of the Podocarpaceae and other types of conifers.

The variety of depositional settings inferred on the basis of palaeobotanical and palynological evidence is also well supported by sedimentological data, which previously established the sedimentary environments as marine-influenced estuarine/deltaic (Moreau 1978, 1993a-c; Néraudeau et al. 1997; Perrichot, 2003).

\subsubsection{Conifers and resin production}

In Charentes, amber has been recovered from different lithologies including mudstones and sandstones showing a range of sedimentary structures and yielding relatively heterogeneous faunas and macrofloras. The palynological data presented herein also indicate a relatively wide variety of depositional settings associated with paralic environments. The fact that amber has been found in these lithologically varied strata is probably related to intrinsic characteristics 
enhancing its transport such as its relatively low density and capacity to harden quickly by comparison with lithological clasts and unconsolidated sediments.

The botanical affinities of Cretaceous amber-producers are still poorly understood. Recent studies have related them to the Araucariaceae or Cheirolepidiaceae (Alonso et al., 2000; Najarro et al., 2009, 2010; Menor-Salván et al., 2010; Nohra et al., 2015; Kvaček et al., 2018). Palynological and palaeobotanical results obtained so far in Charentes and Spain (Barron et al., 2015; Rodriguez-Lopez et al., in press) clearly indicate the presence of representatives of both families in the vegetation. An unequivocal physical relationship between the amber recovered and preserved resin-producing organs will, however, be needed to confirm the botanical derivation. It is interesting to note that both modern (Moss and Kershaw, 2000; Moss et al., 2005) and fossil Araucariaceae produce pollen with limited dispersal potential (de Jekhowsky, 1963; Siegl-Farkas, 1994; Peyrot et al., 2011). Both palynofloral and palaeobotanical data would then represent a coherent and undistorted picture of source vegetation. The fairly common record of Araucariacites spp., Balmeiopsis spp. and Uesuguipollenites spp. in some of the Charentes assemblages indicates the presence of diverse communities of Araucariaceae in close proximity to the depositional settings and suggests a short transport history of the amber to the outcrops rather than a mixing from two sources (local and regional).

\subsubsection{Comparison with neighbouring areas}

During the mid-Cretaceous, the Western European floras were characterized by a relatively large number of species relative to those from boreal latitudes. A higher taxonomic diversity has been recorded for the angiosperms, conifers, ephedroids and free-sporing plants in both macro- and palynofloral assemblages (Lidgard and Crane, 1990; Vakhrameev, 1991). This trend, still apparent in modern floras (Moran, 2008), illustrates a general pattern in which increasing biotic diversity at lower latitudes is probably related to the latitudinal gradient of the climate (Sepkovski, 1997).

The subdominant position assumed by Classopollis in the successions of Charentes clearly connects the flora with others recorded from Europe and North America, characterizing the 
Laurasian Euro-Sinian phytogeographic province (Vakhrameev, 1991). It is interesting to note that Classopollis and cheirolepid macro-remains are usually recorded in lower numbers from mid-Cretaceous assemblages from higher latitudes (Singh, 1964, 1971; Kemp, 1970; Vakhrameev, 1991) than in southern Europe (Diéguez et al., 2010; Barron et al., 2015; Rodríguez-López et al., in press) and from more tropical palaeolatitudes (Salard-Cheboldaeff and Boltenhagen 1992). The Charentes palynofloras apparently represent an intermediate position in the overall distribution pattern, which might be associated with a presumed high equator to pole thermal gradient (Ladant and Donnadieu, 2016).

The high proportion of Anemiaceae and Gleicheniaceae relates the palynological assemblages from Charentes to the palynofloras previously described from southern England (Kemp, 1970) and the Atlantic Coastal Plain of the USA (Brenner, 1963; Ludvigson et al., 2010 and references therein). The presence of these taxa is interpreted to indicate dry local conditions and habitat disturbance.

The large number of inaperturate pollen grains is an uncommon feature which distinguishes the palynofloras of Charentes from other mid-Cretaceous successions. Although recorded in large numbers from contemporaneous assemblages in Western and Central Europe and Northern America, they reached unusually high proportions in the Charentes assemblages. Mesozoic inaperturate pollen grains are usually thought to have been produced by representatives of the Cupressaceae. This relatively large family of conifers includes shrubs and trees that have a wide array of ecological requirements. The large number of spores along with the presence of pollen grains derived from aquatic angiosperms in the assemblages suggests the presence of freshwater bodies, and associated periodically water-logged, mesic, habitats, matching the ecological requirements of certain taxodioids. It is likely that the large numbers of inaperturate pollen grains recorded have been sourced from plants with similar ecological requirements. A freshwater swamp vegetation dominated by taxodioids can be inferred on this basis. It is of interest to note that the presence of an extended area of swamp is currently not supported by local geology (e.g. thick and widespread coal deposits are absent). As such, the extent of the wetlands could have been rather limited in Charentes during the mid-Cretaceous. 


\section{- Conclusions}

The lower Cenomanian outcrops of Charentes have yielded diverse palynofloras consisting of miospores, freshwater algae, acritarchs and dinocysts. Biostratigraphic markers in both the terrestrial and marine palynological assemblages recorded in the studied intervals confirm an early Cenomanian age based previously on micropalaeontological (ostracods and foraminifers) evidence.

Variations in the proportions of dinocysts suggest that the outcrops of Charentes were subject to varying marine influence. The heterogeneity of depositional settings is also reflected by differing miospore associations. Spores comprise between one-quarter and half of the terrestrial palynofloras except in one sample (Aix Island Bois-Joli, LB2), in which they are dominant. This highly distinctive feature probably indicates a very local plant community dominated by sporeproducers (lycophytes and ferns).

Gymnosperms are mainly represented by pollen of the Cupressaceae, Cheirolepidiaceae and, to a lesser extent Araucariaceae and Podocarpaceae. The last of these was recorded in higher numbers together with Pinaceae and marine palynomorphs in level LB1 from Aix Island (BoisJoli), suggesting a short-lived shift to more distal depositional settings. Various vegetation types involving conifers have been inferred. Coastal xeric habitats consisted of cheirolepid trees and an understory of drought-tolerant ferns such as Anemiaceae and Matoniaceae. Locally, and relatively close to the depositional sites, representatives of the Podocarpaceae may have been shrubs and/or trees. Angiosperms were associated with various types of vegetation, including presumably aquatic, hygrophilous and frequently disturbed associations. They were also to be found in the more xeric, cheirolepid-dominated forest associations. The development of backswamp and wetland environments dominated by taxodioids proposed herein, and salt-influenced "mangroves" dominated by cheirolepids needs further supporting evidence to be fully validated.

The taphonomic implications of the results presented are significant as they indicate the existence of various types of amber accumulations (proximal and distal) and suggest the 
presence of a regional source-vegetation consisting of bisaccate pollen grains derived from representatives of the Pinaceae and Podocarpaceae.

Spores associations, dominated by morphotypes attributed to the Anemiaceae and Gleicheniaceae, support the presence of relatively dry coastal and/or frequently disturbed environments. Angiosperm communities included probable herbaceous plants associated with more mesic conditions and/or water saturated environments including representatives of the Chloranthaceae and Nelumbonaceae.

In conclusion, the palynological data of Charentes suggest the presence of five vegetation types:

- Herbaceous thickets comprising representatives of the Gleicheniaceae and several eudicots, which may have colonised frequently disturbed, fluvial, open environments.

- Xeric arboreal communities dominated by Cheirolepidiaceae and probably comprising drought and/or salt tolerant representatives of the Araucariaceae, Ginkgoales and possibly the Cycadales, Gnetales and angiosperms. The understoreys of these forests could have included sporeproducers (Anemiaceae and Gleicheniaceae) that were able to tolerate dry locations.

- Riparian and wetland communities of taxodioid forests with aquatic and/or hygrophilous angiosperms, ferns (including water ferns), lycopods, mosses and clubmosses.

- Coastal/?lagoonal communities including plants tolerant of periodic flooding by saline or brackish waters, such as "mangrove" cheirolepids.

- Conifer forests mainly consisting of representatives of the Pinaceae and Podocarpaceae in raised hinterlands.

\section{Acknowledgements}

We are greatly indebted to the owners of the quarries of Archingeay-Les Nouillers, Cadeuil and Les Renardières for free access to the outcrops and sampling. The manuscript was significantly improved thanks to the critical reviews of J. Galloway and Ulrich Heimhofer. Part of this research has been financed and carried out within projects HF2004-0053 and Project CRE: Cretaceous Resin Event: Global bioevent of massive resin production at the initial diversification of modern forest ecosystems, funded by the Spanish AEI/FEDER, UE Grant CGL2017-84419”. 


\section{References}

Abbink, O.A., Van Konijnenburg-Van Cittert, J.H.A., Visscher, H., 2004. A sporomorph ecogroup model for the Northwest European Jurassic-Lower Cretaceous: concepts and framework.Geologie en Mijnbouw 83, 17-31.

Alonso, J., Arillo, A., Barrón, E., Corral, J.C., Grimalt, J., López, J.F., López del Valle, R.,

Delclòs, X., Ortuño, V., Peñalver, E., Trincao, P., 2000. A new fossil resin with biological inclusions in Lower Cretaceous deposits from Alava (NorthernSpain, Basque-Cantabrian Basin). Journal of Paleontology 74 (1), 158-178.

Alvin, K.L., 1982. Cheirolepidiaceae: Biology, structure and paleoecology. Review of Palaeobotany and Palynology 37, 71-98.

Azéma, C., Ters, M., 1971. Étude palynologique préliminaire du gisement céno-manien de la Bironnière, Vendée (France). Review of Palaeobotany andPalynology 11, 267-282.

Azéma, C., Durand, S., Médus, J., 1972. Des miospores du Cénomanien moyen. Paléo-biologie Continentale 3, 1-54.

Azéma, C., Fauconnier, D., Neumann, M., 1990. Apport de données palynologiques àl'étude du Cénomanien de part et d'autre du seuil de Poitou (France). Revue deMicropaléontologie $33,3-23$.

Barrón, E., Peyrot, D., Rodríguez-López, J.P., Meléndez, N., López Del Valle, R., Najarro, M., Rosales, I., Comas-Rengifo, M.J., 2015. Palynology of Aptian and upper Albian (Lower Cretaceous) amber-bearing outcrops of the southern margin of the Basque-Cantabrian Basin (northern Spain). Cretaceous Research 52, 292-312.

Batten, D.J., 1974. Wealden palaeoecology from the distribution of plant fossils. Proceedings of the Geologists' Association 85, 433-457.

Batten, D.J., 1999. Small palynomorphs. In: Jones, T.P., Rowe, N.P. (eds.), Fossil plant and spores modern techniques. The Geological Society, London, UK, pp. 15-19.

Batten, D.J., Collinson, M.E., 2001. Revision of species of Minerisporites, Azolla and associated plant microfossils from deposits of the Upper Palaeocene and Palaeocene/Eocene transition in the Netherlands, Belgium and the USA. Review of Palaeobotany and Palynology 115, $1-32$. 
Batten, D.J., Collinson, M.E., Knobloch, E., 1994. Ariadnaesporites and Capulisporites: "water fern" megaspores from the Upper Cretaceous of Central Europe. Review of Palaeobotany and Palynology 83, 159-174.

Batten, D.J., Koppelhus, E.B., 1996. Chapter 20D. Biostratigraphic significance of uppermost Triassic and Jurassic miospores in Northwest Europe. In: Jansonius, J., McGregor, D.C. (Eds.), Palynology: Principles and Applications: American Association of Stratigraphic Palynologists Foundation, vol. 2, pp. 795-806.

Batten, D.J., Colin, J-P., Néraudeau, D., 2010. Megaspores from mid Cretaceous deposits in western France and their biostratigraphic and palaeoenvironmental significance. Review of Palaeobotany and Palynology 161, 151-167.

Berner, R. A., 2003. The long-term carbon cycle, fossil fuels and atmospheric composition. Nature 426, 323-326.

Birks, H.J.B., Birks, H.H., 1980. Quaternary palaeoecology. Edward Arnold, London.

Boyce, C.K., Brodribb, T.J., Field, T.S., Zwieniecki, M.A., 2009. Angiosperm leaf vein evolution was physiologically and environmentally transformative. Proceedings of the Royal Society B 276, 1771-1776.

Brenner, G. J., 1963. The spores and pollen of the Potomac Group of Maryland. Maryland Department of Geology, Mines and Water Resources Bulletin 27, 1-215.

Coiffard, C., Gomez, B., Kvaček, J., Thévenard, F., 2006. Early angiosperm ecology: evidence of Albian-Cenomanian of Europe. Annals of Botany 98, 495-502.

Coiffard, C., Gomez, B., Thiébaut, M., Kvaček, J., Thévenard, F., Néraudeau, D., 2009. Inframarginal veined lauraceae leaves from the Albian-Cenomanian of Charente-Maritime (western France). Palaeontology 52 (2), 323-336.

Colin, J.P., 1974. Contribution à l'étude des ostracodes du Crétacé supérieur de Dordogne (France). Geobios 7, 19-42.

Costa, L.I., Davey, R.J., 1992. Dinoflagellate cysts of the Cretaceous System. In: Powel, A.J. (Ed.), A stratigraphic index of dinoflagellate cysts. Chapman and Hall, London, pp. 99131.

Damotte, R., Babinot, J.F., Colin, J.P., 1981. Les ostracodes du Crétacé Moyen Européen. Cretaceous Research 2, 287-306. 
Davey, R.J., Rogers, J., 1975. Palynomorph distribution in recent offshore sediments along two traverses off southwest Africa. Marine Geology 18 (3), 213-225.

Deák, M.H., Combaz, A., 1967. "Microfossiles organiques" du Wealdien et du Cénomanien dans un sondage de Charente-Maritime. Revue de Micropaléontologie 10 (2), 69-96.

Dejax, J., Masure, E., 2005. Analyse palynologique de l'argile lignitifère à ambre de l'Albien terminal d'Archingeay (Charente-Maritime, France). Comptes Rendus Palevol 4, 53-65.

Diéguez, C., Peyrot, D., Barrón, E., 2010. Floristic and vegetational changes in the Iberian Peninsula during Jurassic and Cretaceous. Review of Palaeobotany and Palynology 162, $325-340$.

Doyle, J.A., 1992. Revised palynological correlations of the lower Potomac Group (USA) and the Cocobeach sequence of Gabon (Barremian-Aptian). Cretaceous Research 13, 337-349.

Doyle, J.A., Robbins, E.I., 1977. Angiosperm pollen zonation of the Continental Cretaceous of the atlantic coastal plain and its application to deep wells in the Salisbury embayment. Palynology 1, 43-78.

Doyle, J.A., Endress, P.K. 2014. Integrating Early Cretaceous fossils into the phylogeny of living angiosperms: ANITA lines and relatives of Chloranthaceae. International Journal of Plant Science $175,555-600$.

El-Beialy, S.Y., El Atfy, H.S., Zavada, M.S., El Khoriby, E.M., Abu-Zie, R.H., 2010. Palynological, palynofacies, paleoenvironmental and organic geochemical studies on the Upper Cretaceous succession of the GPTSW-7 well, North Western Desert, Egypt. Marine and Petroleum Geology 27, 370-385.

Farjon, A., 2005. A monograhp of Cupressaceae and Sciadopitys. Royal Botanic Gardens, Kew.

Feild, T.S., Arens, N.C., Doyle, J.A., Dawson, T.E., Donoghue, M.J., 2004. Dark and disturbed: a new image of early angiosperm ecology. Paleobiology 30, 82-107.

Ferguson, D.K., 1995. Plant part processing and community reconstruction. Eclogae Geologicae Helvetica 88, 627-641.

Foucher, J.C., Monteil, E., 1998. Cretacous biochronostratigraphy, dinoflagellate cysts. In: De Graciansky, P.-C., Hardenbol, J., Jacquin, T. (Eds.), Mesozoic and Cenozoic sequence stratigraphy of European basins. Society of Economic Paleontologists and Mineralogists, Tulsa, Special Publication, Chart 5. 
Friedrich, O., Norris, R.D., Erbacher, J., 2012. Evolution of middle to Late Cretaceous oceans A 55 m.y. record of Earth's temperature and carbon cycle. Geology 40, 107-110.

Friis, E.M., Crane, P.R., Pedersen, K.R., 2011. Early flowers and angiosperm evolution. Cambridge University Press, Cambridge.

Gomez, B., Daviero-Gomez, V., Perrichot, V., Thévenard, F., Coiffard, C., Philippe, M., Néraudeau, D., 2004. Assemblages floristiques de l'Albien-Cénomanien de CharenteMaritime (SO France). Annales de Paléontologie 90, 147-159.

Gomez, B., Coiffard, C., Dépré, É., Daviero-Gomez, V., Néraudeau, D., 2008. Diversity and histology of a plant litter bed from the Cenomanian of Archingeay-Les Nouillers (southwestern France). Comptes Rendus Palevol 7, 135-144.

Grimm, E.C., 1992. Tilia, Version 2. Illinois State Museum, Research and Collection Center, Springfield.

Grimm, E.C., 2004. TGView, Version 2.0.2. Illinois State Museum, Research and Collections Center, Springfield.

Haas, J., Tardi-Filacz, E., Oravecz-Scheffer, A., Grczýn, F., 1997. Stratigraphy and sedimentology of an Upper Triassic Tope-of-Slop and Basin succession at Csovar, North Hungary. Acta Geologica Hungarica 40 (2), 111-177.

Harris, T. M., 1961. The Yorkshire Jurassic Flora. I. Thallophyta-Pteridophyta. British Museum (Natural History), London.

Hay, W.W., Floegel, S., 2012. New thoughts about the Cretaceous climate and oceans. EarthScience Reviews 115, 262-272.

Herendeen, P.S., Friis, E.M., Perdersen, K.R. Crane, P.R. 2017. Palaeobotanical redux: revisiting the age of the angiosperms. Nature Plants 17015, DOI: 101038/nplants.2017.15.

Hochuli, P. A., Heimhofer, U., Weissert, H., 2006. Timing of early angiosperm radiation: recalibrating the classical succession. Journal of the Geological Society, London 163, 587594.

Horiks, M., Hochuli, P.A., Feist-Burkhardt, S., Heimhofer, U. 2016. Albian angiosperm pollen from shallow marine strata in the Lusitanian Basin, Portugal. Review of Palaeobotany and Palynology 228, 67-92.

Hughes, N.F., 1994. The enigma of angiosperm origins. Cambridge University Press, Cambridge, p. 303. 
Jacobson Jr., G.L., Bradshaw, R.H.W., 1981. The selection of sites for paleovegetational studies. Quaternary Research 16, 80-96.

de Jekhowsky, B., 1963. Variations latérales en palynologie quantitative et passage du continental au marin. Le Dogger Supérieur du Sud-ouest de Madagascar. Revue de l'institut français du pétrole et Annales des combustibles liquides 18, 977-995.

Keller, C.E., Hochuli, P.A., Weissert, H., Bernasconi, S., Giorgioni, M., Garcia, T.I., 2011. A volcanically induced climate warming and floral change preceded the onset of OAE1a (Early Cretaceous). Palaeogeography, Palaeoclimatology, Palaeoecology 305, 43-49.

Kemp, E.M., 1970. Aptian and Albian miospores from Southern England. Palaeontographica Abteilung B 131 (1-4), 73-142.

Kergoat, G.J., Bouchard, P., Clamens, A.L., Abbate, J.L., Jourdan, H., Jabbour-Zahab, R., Genson, G., Soldati, L., Condamine, F. L., 2014. Cretaceous environmental changes led to high extinction rates in a hyperdiverse beetle family. BMC Evolutionary Biology 14, 220233.

Kershaw, A.P., 1976. A Late Pleistocene and Holocene pollen diagram from Lynch's Crater, northeastern Queensland, Australia. New Phytologist 77, 469-498.

Kvaček, J., Gomez, B., Zetter, R., 2012. The early angiosperm Pseudoasterophyllites cretaceous from Albian-Cenomanian of Czech Republic and France. Acta Palaeontologica Polonica 57 (2), 437-443.

Kvaček, J., Doyle, J.A., Endress, P.K., Daviero-Gomez, V., Gomez, B., Tekleva, M., 2016. Pseudoasterophyllites cretaceous from the Cenomanian (Cretaceous) of the Czech Republic: a possible link between Chloranthaceae and Ceratophyllum. Taxon 65 (6), 13451373.

Kvaček, J., Barrón, E., Heřmanová, Z., Mendes, M.M., Karch, J., Žemlička, J., Dudák, J., 2018. Araucarian conifer from the late Albian amber of Northern Spain. Papers in Palaeontology, doi:10.1002/spp2.1223

Labandeira, C.C., 2006. The Four Phases of Plant-Arthropod Associations in Deep Time. Geologica Acta 4, 409-438.

Ladant, J.-B., Donnadieu, Y., 2016. Palaeogeographic regulation of glacial events during the Cretaceous supergreenhouse. Nature Communication. 7, DOI: 10.1038/ncomms12771. 
Lidgard, S., Crane, P.R., 1990. Angiosperm diversification and Cretaceous floristic trends: a comparison of palynofloras and leaf macrofloras. Paleobiology 16, 77-93.

Littler, K., Robinson, S.A., Bown, P.R., Nederbragt, Alexandra J., Pancost, R.D., 2011. High sea-surface temperatures during the Early Cretaceous Epoch. Nature Geoscience 4, 169172.

Lloyd, G.T., Davis, K.E., Pisani, D., Tarver, J.E., Ruta, M., Sakamoto, M., Hone, D.W.E., Jennings, R., Benton, M.J., 2008. Dinosaurs and the Cretaceous Terrestrial Revolution. Proceedings of the Royal Society B 275, 2483-2490.

Ludvigson, G.A., Witzke, B.J., Joeckel, R.M., Ravn, R.L., Phillips, P.L., González, L.A., Brenner, R.L., 2010. New insights on the sequence stratigraphic architecture of the Dakota Formation in Kansas-Nebraska-Iowa from a decade sponsored research activity. Current Research in Earth Sciences, Bulletin 258 (2), 1-35.

Mädler, K.A., 1964. Die Geologische Verbreitung von sporen und pollen in der Deutschen Trias. Beihefte zum Geologischen Jahrbuch 65, 1-147.

McCarthy, F.M.G., Mudie, P.J., 1998. Oceanic pollen transport and pollen: dinocyst ratios as markers of late Cenozoic sea level change and sediment transport. Palaeogeography Palaeoclimatology Palaeoecology, 138(1-4): 187-206.

McCarthy, F.M.G., Mudie, P.J., 2006. Marine palynology: potentials for onshore-offshore correlation of Pleistocene-Holocene records. Transactions of the Royal Society of South Africa 61 (2), 139-157.

Mehltreter, K, Walker, L.R., Sharpe, J.M., 2012. Fern ecology. Cambridge University Press, Cambridge.

Menor-Salván, C., Najarro, M., Velasco, F., Rosales, I., Tornos, F., Simoneit, B.R.T., 2010. Terpenoids in extracts of Lower Cretaceous ambers from the Basque-Cantabrian Basin (El Soplao, Cantabria, Spain): Paleochemotaxonomic aspects. Organic Geochemistry 41 (10), 1089-1103.

Meredith, R.W., Janečka, J.E., Gatesy, J., Ryder, O.A., Fisher, C.A., Teeling, E.C., Goodbla, A., Eizirik, E., Simão, T.L.L., Stadler, T., Rabosky, D.L., Honeycutt, R.L., Flynn, J.J., Ingram, C.M., Steiner, C., Williams, T.L., Robinson, T.J., Burk-Herrick, A., Westerman, M., Ayoub, N.A., Springer, M.S., Murphy, W.J., 2011. Impacts of the Cretaceous Terrestrial Revolution and KPg Extinction on mammal diversification. Science 334, 521-524. 
Meunier, A., Proust, D., Moreau, P., 1999. Geological significance of two smectite-rich beds from Lower Cenomanian sediments, northern Aquitaine Basin, France. Bulletin de la Societé Géologique de France 170 (6), 873-882.

Morbey, S.J., 1975. The palynostratigraphy of the Rhaetian Stage, Upper Triassic in the Upper Kendelbachgraben, Austria. Palaeontographica Abteilung B 52, 1-75.

Moran, R.C. 2008. Diversity, biogeography, and floristics. in: Ranker, T.A and Haufler, C.H. (Eds) Biology and evolution of ferns and lycophytes. Cambridge University Press, Cambridge, pp. 367-394.

Moreau, P., 1978.Le role du Plateau Central dans la paléogéographie nord-aquitaine au Cénomanien. Géologie Méditerraneénne 5 (1), 125-136.

Moreau, P., 1993a. La transgression Cénomanien sur le marge septentrionale du basin de l'Aquitaine (Charentes), flanc Nord du synclinal de Saintes et Angoumois. Modalités d'une invasion marine, aspects stratigraphiques, sédimentologiques et paléogéographiques. I. Analyse stratigraphique et identification des milieux. Thèse d'Etat. Université de Poitiers, France.

Moreau, P., 1993b. La transgression Cénomanien sur la marge septentrionale du basin de l'Aquitaine (Charentes), flanc Nord du synclinal de Saintes et Angoumois. Modalités d'une invasion marine, aspects stratigraphiques, sédimentologiques et paléogéographiques. II. La sedimentation terrigène et glauconieuse: caracterisation et distribution des éléments. Thèse d'Etat. Université de Poitiers, France.

Moreau, P., 1993c. La transgression Cénomanien sur le marge septentrionale du basin de l'Aquitaine (Charentes), flanc Nord du synclinal de Saintes et Angoumois. Modalités d'une invasion marine, aspects stratigraphiques, sédimentologiques et paléogéographiques. III. Paléontologie stratigraphique et biochronologique. Paléogéographie et structure. Thèse d'Etat. Université de Poitiers, France.

Moreau, J.-D., Néraudeau, D., Gomez, B., Tafforeau, P., Dépré, É., 2014. Inclusions of conifers, echinoids, foraminifers and sponges in flints from the Cenomanian of Charente-Maritime (France): Contribution of synchrotron microtomography. Comptes Rendus Palevol 13, $455-461$. 
Moreau, J.-D., Néraudeau, D., Philippe, M., Dépré, E., 2017. Albian flora from Archingeay-Les Nouillers (Charente-Maritime): comparison and synthesis of Cretaceous meso- and macroremains from the Aquitaine Basin (southwestern France). Geodiversitas 39, 729-740.

Moss, P.T., Kershaw, A.P., 2000. The last glacial cycle from the humid tropics of northeastern Australia: comparison of a terrestrial and marine record. Palaeogeography Palaeoclimatology Palaeoecology 155, 155-176.

Moss, P.T., Kershaw, A.P. Grindrod, J., 2005. Pollen transport and deposition in riverine and marine environments within the humid tropics of northeastern Australia. Review of Palaeobotany and Palynology 134, 55- 69.

Mudie, P. J., McCarthy, F.M.G., 1994. Late Quaternary pollen transport processes, western North Atlantic: Data from box models, cross-margin and N-S transects. Marine Geology $118,79-105$.

Najarro, M., Peñalver, E., Rosales, I., Perez-de la Fuente, R., Daviero-Gomez, V., Gomez, B., Delclòs, X., 2009. Unusual concentration of Early Albian arthropodbearing amber in the Basque-Cantabrain Basin (El Soplao, Cantabria, Norhern Spain): Palaeoenvironmental and palaeobiological implications. Geologica Acta 7 (3), 363-387.

Najarro, M., Peñalver, E., Pérez de la Fuente, R., Ortega-Blanco, J., Menor-Salván, C., Barrón, E., Soriano, C., Rosales, I., López del Valle, R., Velasco, F., Tornos, F., Daviero-Gomez, V., Gomez, B., Delclòs, X., 2010. Review of the El Soplao Amber Outcrop, Early Cretaceous of Cantabria, Spain. Acta Geologica Sinica 84, 959-976.

Néraudeau, D., Moreau, P., 1989. Paléoécologie et paléobiogéographie des faunes d'échinides du Cénomanien nord-aquitain (Charente-Maritime, France). Géobios 22, 293-324.

Néraudeau, D., Thierry, J., Moreau, P., 1997. Variation in echinoid biodiversity during the Cenomanian-early Turonian transgressive episode in Charentes. Bulletin de la Société géologique de France 168, 51-61.

Néraudeau, D., Perrichot, V. Dejax, J., Masure, E., Nel, A., Philippe, M., Moreau, P., Guillocheau, F., Guyot, T., 2002. Un nouveau gisement à ambre insectifère et à végétaux (Albien terminal probable): Archingeay (Charente-Maritime, France). Geobios 35, 233240.

Néraudeau, D., Allain, R. Perrichot, V., Videt, B., de Lapparent de Broin, J., Guillocheau, F., Philippe, M., Rage, J.-C., Vullo, R., 2003. Découverte d'un dépôt paralique à bois fossiles, 
ambre insectifère et restes d'Iguanodontidae (Dinosauria, Ornithopoda) dans le Cénomanien inférieur de Fouras (Charente-Maritime, Sud-Ouest de la France). Comptes Rendus Palevol 2, 221-230.

Néraudeau, D., Vullo, R., Gomez, B., Perrichot, V., Videt, B., 2005. Stratigraphie et paléontologie (plantes, vertébrés) de la série paralique Albien terminal-Cénomanien basal de Tonnay-Charente (Charente-Maritime, France). Comptes Rendus Palevol 4, 79-93.

Néraudeau, D., Perrichot, V., Colin, J.-P., Girard, V., Gomez, B., Guillocheau, F., Masure, E., Peyrot, D., Tostain, F., Videt, B., Vullo, R., 2008. A new amber deposit from the Cretaceous (uppermost Albian-lowermost Cenomanian) of southwestern France. Cretaceous Research 29, 925-929.

Néraudeau, D., Vullo, R., Gomez, B., Girad, V., Lak, M., Videt, B., Dépré, É., Perrichot, V., 2009. Amber, plant and vertebrate fossils from the Lower Cenomanian paralic facies of Aix Island (Charente-Maritime, SW France). Geodiversitas 31, 13-27.

Néraudeau, D., Perrichot, V., Batten, D.J., Boura, A., Girard, V., Jeanneau, L., Nohra, Y.A., Polette, F., Saint-Martin, S., Saint-Martin, J-P., Thomas, R., 2017. Upper Cretaceous amber from Vendée, north-western France: Age dating and geological, chemical, and palaeontological characteristics. Cretaceous Research 70, 77-95.

Nohra, Y.A., Perrichot, V., Jeanneau, L., Le Pollès, L., Azar, D., 2015. Chemical Characterization and Botanical Origin of French Ambers. Journal of Natural Products 78, 1284-1296.

Pacltová, B., 1968. Some new pollen grains from the Bohemian Cenomanian. Review of Palaeobotany and Palynology 7, 99-106.

Peris, D., Pérez-de la Fuente, R., Peñalver, E., Delclòs, X., Barrón, E., Labandeira, C.C., 2017. False Blister Beetles and the Expansion of Gymnosperm-Insect Pollination Modes before Angiosperm Dominance. Current Biology 27 (6), 897-904.

Perrichot, V., 2003. Environnements paraliques à ambre et a végétaux du Crétacé Nord-Aquitain (Charentes, Sud-Ouest de la France). Ph.D. Thesis. Université de Rennes, Rennes, France, 310pp.

Perrichot, V., Néraudeau, D. Nel, A., De Ploeg, G., 2007. A reassessment of the Cretaceous amber deposits from France and their palaeontological significance. African Invertebrates $48,213-227$. 
Peyrot, D., Jolly, D., Barrón, E., 2005. Apport de données palynologiques à la reconstruction paléoenvironnementale de l'Albo-Cénomanien des Charentes (Sud-Ouest de la France). Comptes Rendus Palevol 4, 151-165.

Peyrot, D., Rodríguez- López, J.P., Lassaletta, L., Meléndez, N., Barrón, E., 2007. Contributions to the palaeoenvironmental knowledge of the Escucha Formation in the Lower Cretaceous Oliete Sub-basin, Teruel, Spain. Comptes Rendus Palevol 6, 469-481.

Peyrot, D., Barroso-Barcenilla, F., Barrón, E., Comas-Rengifo, M.J., 2011. Palaeoenvironmental analysis of CenomanianeTuronian dinocyst assemblages from the Castilian Platform (Northern-Central Spain). Cretaceous Research 32, 504-526.

Planderová, E., 1980. Palynomorphs from Lunz Beds and from Black Clayey Shales in basement of Vienna Basin, (Borehole LNV-7). Geologica Carpathica 31(3), 267-294.

Prentice, I.C., 1988. Records of vegetation in time and space: the principles of pollen analysis., in: Huntley, B., Webb III, T. (Eds.), Vegetation History. Kluwer, Dordrecht, pp. 17-42.

Proctor, M.C.F., Tuba, Z., 2002. Poikilohydry and homoihydry: antithesis or spectrum of possibilities? New Phytologist, 156: 327-349.

Ravn, R.L., 1995. Miospores from the Muddy Sandstone (upper Albian), Wind River Basin, Wyoming, USA. Palaeontographica Abteilung B 234 (3-6), 41-91.

Rodríguez-López, J.P., Peyrot, D., Barrón, E., Meléndez, N., in press. Plate margin desert basins; sedimentology, cyclicity and palaeohabitats. A Cretaceous Iberian analogue for reliefcontrolled narrow Holocene desert coasts. Sedimentology.

Salard-Cheboldaeff, M., Boltenhagen, E., 1992. La palynologie des évaporites d'Afrique équatoriale et ses rapports avec le paléoenvironnement. Journal of African Earth Science 14, 194-195.

Sepkovski, J.J. 1997. Biodiversity: past, present and future. Journal of Paleontology 71, 533539.

Singh, C., 1964. Microflora of the Lower Cretaceous Mannville group, East-Central Alberta. Research Council of Alberta Bulletin 15, 1-238.

Singh, C., 1971. Lower Cretaceous microfloras of the Peace River Area, Northwestern Alberta. Research Council of Alberta Bulletin 28 (1), 1-299.

Siegl-Farkas, Á, 1994. Palynologische Untersuchungen an ausgewählten Vorkommen der Gosauschichten Österreichs. In: Lobitzer, H., Császár, G., Daurer, A. (Eds.), 
Jubiläumsschrift 20 Jahre Geologische Zusammenarbeit Österreich-Ungarn, Teil 2, pp. 107-122. Wien.

Spackman, W., Riegel W.L., Dolsen C.P., 1969. Geological and biological interactions in the swamp-marsh complex of southern Florida, in: Dapples, E.C., Hopkins M.E. (Eds.), Environments of coal deposition. Special Paper of the Geological Society of America, Boulder, pp. 1-35

Spicer, R.A., 1991. Plant taphonomic processes, in: Allison, P.A., Briggs, B.G. (Eds.), Taphonomy releasing: the data locked in the fossil record. Plenum Press, New York, London. pp. 71-113.

Stockey, R. A., Kvaček, J., Hill, R.S., Rothwell, G.W., Kvaček, Z., 2005. The fossil record of Cupressaceae s. lat. In: Farjon, A. (Ed.), A monograhp of Cupressaceae and Sciadopitys. Royal Botanic Gardens, Kew, pp. 54-68.

Taylor, D. W., Hu, S., 2010. Coevolution of early angiosperms and their pollinators: Evidence for pollen. Palaeontographica Abteilung B, 283, 103-135.

Taylor, T.N., Taylor, E.L., Krings, M., 2009. Paleobotany. The biology and evolution of fossil plants. Elsevier, Amsterdam.

Tryon, R.M., Tryon, A.F., 1982. Ferns and Allied Plants. Springer-Verlag, New York.

Traverse, A., 2007. Paleopalynology. 2nd Edition. Springer, Dordrecht.

Vakhrameev, V.A., 1991. Jurassic and Cretaceous floras and climates of the Earth. Cambridge University Press, Cambridge.

Visscher, H., Brugman, W.A., 1981. Ranges of selected palynomorphs in the Alpine Triassic of Europe. Review of Palaeobotany and Palynology 34, 115-128.

Vullo, R., D. Néraudeau, B. Videt. 2003. Un faciès de type falun dans le Cé nomanien basal de Charente-Maritime (France). Annales de Paléontologie 89, 171-189.

Vullo, R., D. Néraudeau, R. Allain, H. Cappetta. 2005. Un nouveau gisement à microrestes de vertébrés continentaux et littoraux dans le Cénomanien inférieur de Fouras (CharenteMaritime, Sud-Ouest de la France). Comptes Rendus Palevol 4, 95-107.

Vullo, R., H. Cappetta, D. Néraudeau. 2007a. New sharks and rays from the Cenomanian and Turonian of Charentes, France. Acta Palaeontologica Polonica 52, 99-116. 
Vullo, R., D. Néraudeau, T. Lenglet. 2007b. Dinosaur teeth from the Cenomanian of Charentes, western France: evidence for a mixed Laurasian-Gondwanan assemblage. Journal of Vertebrate Paleontology 27, 931-943.

Ward, J.V., 1986. Early Cretaceous angiosperm pollen from the Cheyenne and Kiowa formations (Albian) of Kansas, U.S.A. Palaeontographica Abteilung B 202, 1-81.

Watts, W.A., Hansen, B.C.S., 1994. Pre-Holocene and Holocene pollen records of the vegetation history from the Florida peninsula and their climatic implications, Palaeogeography, Palaeoclimatology, Palaeoecology 109, 163-176.

Willard, D.A., 2001. Pollen assemblages as paleoenvironmental proxies in the Florida Everglades. Review of Palaeobotany and Palynology 113, 213-235.

\section{Figure Captions}

Figure 1. Simplified geological setting of northwestern Charente-Maritime, France (modified from Peyrot et al., 2005)

Figure 2. Stratigraphic sections of Archingeay-Les Nouillers (A) and Cadeuil (B) successions and Les Renardières (C), Fouras (D), Aix Island (Bois-Joli) (E), and La Buzinie (F) outcrops with location of palynological samples and main features.

Figure 3. Circular abundance diagrams of spores, angiosperms and gymnosperms constituting the fertile miospore assemblages of Charentes. When quantitatively relevant, the relative proportion of angiosperms (probable monocots, eudicots [excluding Chloranthaceae], Chloranthaceae and other angiosperms) gymnosperms (Cheirolepidiacea, Araucariaceae, Cupressaceae, Pinaceae and other gymnosperms) and spores (lycophytes, bryophytes [i.e. mosses], Gleicheniaceae, Cyatheaceae/Dicksoniaceae/ /Dipteridaceae, Schizaeaceae and other spore producers) were detailed for each outcrop in the form of a bar-diagram.

Figure 4. Detailed palynological chart for Cadeuil (A) and Archingeay-Les Nouillers (B).

Figure 5. Dinoflagellate cysts from Charentes, scale bars represent $20 \mu \mathrm{m}$. A. Epelidosphaeridia spinosa, sample ARC1; B. Palaeohystrichophora infusorioides, sample ARC-AR4; C. Subtilisphaera sp., sample ARC7; D. Dinopterygium alatum, sample CA-B0; E. Kiokansium sp., sample ARC10; F. Hystrichodinium pulchrum, sample ARC-AR9; G. Spiniferites ramosus, 
sample ARC-AR9; H. Achomosphaera sagena, sample CA-B4; I. Achomosphaera ramulifera, sample CA-B5; J. Circulodinium distinctum, sample LB2; K. Circulodinium brevispinatum, sample LB2; L. Tehamadinium coummium, sample CA-B0.

Figure 6. Acritarchs, prasinophytes, freshwater algae and reworked palynomorphs from

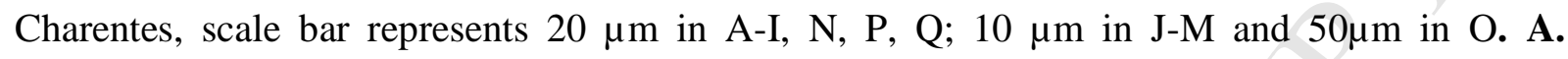
Aratrisporites fimbriatus, sample CA-B5; B. Aratrisporites virgatus, sample ARC1; C. Zebrasportites fimbriatus, sample CA-B5.5; D. Zebrasportites interscriptus, sample CA-B6.5; E-F. Zebrasportites? annulatus (Deák \& Combaz, 1968) comb. nov., E. Sample ARC11, F. Sample ARC15; G. Protodiploxypinus ornatus, sample REN; H. Protodiploxypinus sp., sample REN; I. Rimaesporites sp., sample CA-B5; J. Micrhystridium sp., sample ARC2; K. Mecsekia acuta, sample ARC1; L. Veryachium sp., sample ARC1; M. Cymatiosphaera sp., sample LB2; N. Pleurozonaria sp., sample ARC-AR9; O. Schizosporis reticulatus, sample LB2; P. Ovoidites parvus, sample CA-B6; Q. Tetraporina sp., sample LB2.

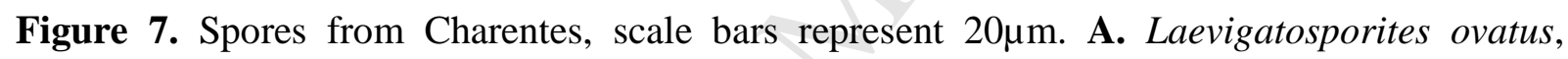
sample REN; B. Laevigatosporites sp., sample CA-B6; C. Peromonolites allenensis, sample ARC-AR-4; D. Reticulosporis gallicus, sample ARC AR-4; E. Reticulosporis foveolatus, sample CA-B2; F. ?Marattisporites sp., sample ARC1; G-H. Stereisporites cf. antiquasporites, G. Sample CA-B5, H. Sample CA-B6; I. Stereigranisporis regius, sample CA-B6; J. Cyathidites australis, sample ARC4; K. Granulatisporites michinus, sample CA-B5; L. Foveotriletes cf. parviretus, sample LB2; M. Ornamentifera spp., sample ARC4; N-O. Clavifera triplex, N. Sample ARC15, O. Degraded specimen, sample CA-B2; P. Plicifera dicarpoides, sample CAB5.5; Q. Plicifera sp., sample CA-B5.5; R. Polycingulatisporites reduncus, sample ARC14; S. Microreticulatisporites sacalii, sample ARC6; T. Microreticulatisporites urkuticus, sample ARC1.

Figure 8. Spores from Charentes, scale bars represent 20 $\mu$ m. A. Camarozonosporites ambigens, sample ARC4; B. ?Camarozonosporites wrennii, sample ARC1; C. Camarozonosporites vermiculaesporites, sample REN; D. Retitriletes austroclavatidites, sample REN; E. Staplinisporites caminus, sample ARC15; F. Costatoperforosporites sp., sample ARC14; G. 
Cicatricosisporites venustus, sample ARC-AR2; H. Cicatricosisporites crassiterminatus, sample ARC11; I. Appendicisporites erdtmanii, sample ARC13; J. Appendicisporites cf. tricuspidatus, sample ARC11; K. ?Appendicisporites bifurcatus, sample ARC11; L. Appendicisporites fucosus, sample LB2; M-N. Appendicisporites cristatus, M. Specimen in polar view, sample ARC2, N. Specimen in equatorial view, sample ARC7; O-P. Appendicisporites potomacensis, sample ARC7, O. Proximal focus, P. Distal focus; Q-R. Lycopodiacidites tortus, distal side, Q. Sample ARC13, R. Sample CA-B5; S. Echinatisporis varispinosus sample ARC-AR7; T. ?Ceratosporites sp., sample ARC2.

Figure 9. Spores and gymnosperm pollen grains from Charentes, scale bars represent $10 \mu \mathrm{m}$ in P$\mathrm{U}$ and $20 \mu \mathrm{m}$ elsewhere. A. Sestrosporites pseudoalveolatus, sample ARC3; B. Concavissimisporites cf. variverrucatus, sample ARC-AR7; C. Trilobosporites sp., sample CAB6.5; D. Osmundacidites wellmanii, sample LB2; E. Uesuguipollenites callosus, sample REN; F. Araucariacites australis, sample REN; G. Balmeiopsis limbata, sample ARC2; H. Perinopollenites halonatus, sample ARC5; I. Taxodiaceaepollenites hiatus, sample ARC-AR9; J. ?Sciadopityspollenites sp., sample CA-B2; K. Classopollis sp., sample ARC-AR9; L. Parvisaccites radiatus, sample REN; M. Alisporites bilateralis, sample ARC2; N. Podocarpidites sp., sample ARC12; O. Rugubivesiculites reductus, sample CA-B4; P. Phyllocladidites minimus, sample ARC-AR7; Q. Cycadopites sp., sample ARC8; R. Eucommiidites troedssonii, sample CA-B5; S. Eucommiidites minor, sample ARC3; T. Equisetosporites multicostatus, sample ARC8; U. Afropollis sp., sample ARC3.

Figure 10. Angiosperm pollen grains from Charentes, scale bars represent $10 \mu \mathrm{m}$. A. Asteropollis trichotomosulcatus, sample ARC10; B. Clavatipollenites minutus, sample ARC5; C. Clavatipollenites sp., sample ARC6; D. Clavatipollenites tenellis, sample CA-B4; E. Monocolpopollenites sp., sample ARC2; F-G. Transitoripollis anulisulcatus, sample CA-B6; HJ. Dichastopollenites dunveganensis, H. Sample CA-B6, I-J., Sample CA-B5.5; K-L. Dichastopollenites ghazalatensis, sample CA-B6; M-P. Dichastopollenites reticulatus, M. Sample ARC10, N-P. Sample CA-B4; Q. Pennipollis reticulatus, sample ARC4; R. Pennipollis cf. peroreticulatus, sample CA-B5; S-X., Dichastopollenites? sp. 1, S. Sample CA-B5, T. Sample CA-B2, U. Sample ARC7, V. Sample CA-B4.5, W. Sample ARC7, X. Sample CA-B6. 
Figure 11. Angiosperm pollen grains from Charentes, scale bars represent $10 \mu \mathrm{m}$. A-B. Tricolpites nemejci, A. Sample ARC9, B. Sample CA-B0; C-D. Retitrescolpites sp. cf. Tricolpites sp. C Doyle \& Robbins, 1977, sample CA-B5; E. Striatopollis sp., sample ARC6; F. Phimopollenites pseudocheros, sample CA-B6.5; G. Penetetrapites mollis, sample CA-B4.5; H. Cretacaeiporites polygonalis, sample ARC-AR9; I. Cretacaeiporites sp., sample ARC7; J. Cretacaeiporites sp.1, sample ARC-AR8; K. Bohemiperiporis zaklinskai, sample ARC-AR7; L. Tricolpites interangulus, ARC-AR9; M. Psilatricolporites sp., sample CA-B5; $\mathbf{N}$. Nyssapollenites sp., sample ARC1; O. Tricolporoidites subtilis, sample ARC4; P. Tricolporoidites sp., sample ARC1; Q. Nyssapollenites triangulus, sample ARC5; R., Nyssapollenites cf. nigricolpus, sample ARC-AR8; S. Retitricolporites cf. pristinus, sample ARC4; T. Foveotricolpites sp. cf. Tricolpites sp. 2 Agasie, 1969, sample CA-B5.5; U. Rousea doylei, sample CA-B0; V. Foveotricolporites callosus, sample CA-B5; W. Artiopollis indivisus, sample ARC9; X. Senectotetradites grossus, sample ARC13. 


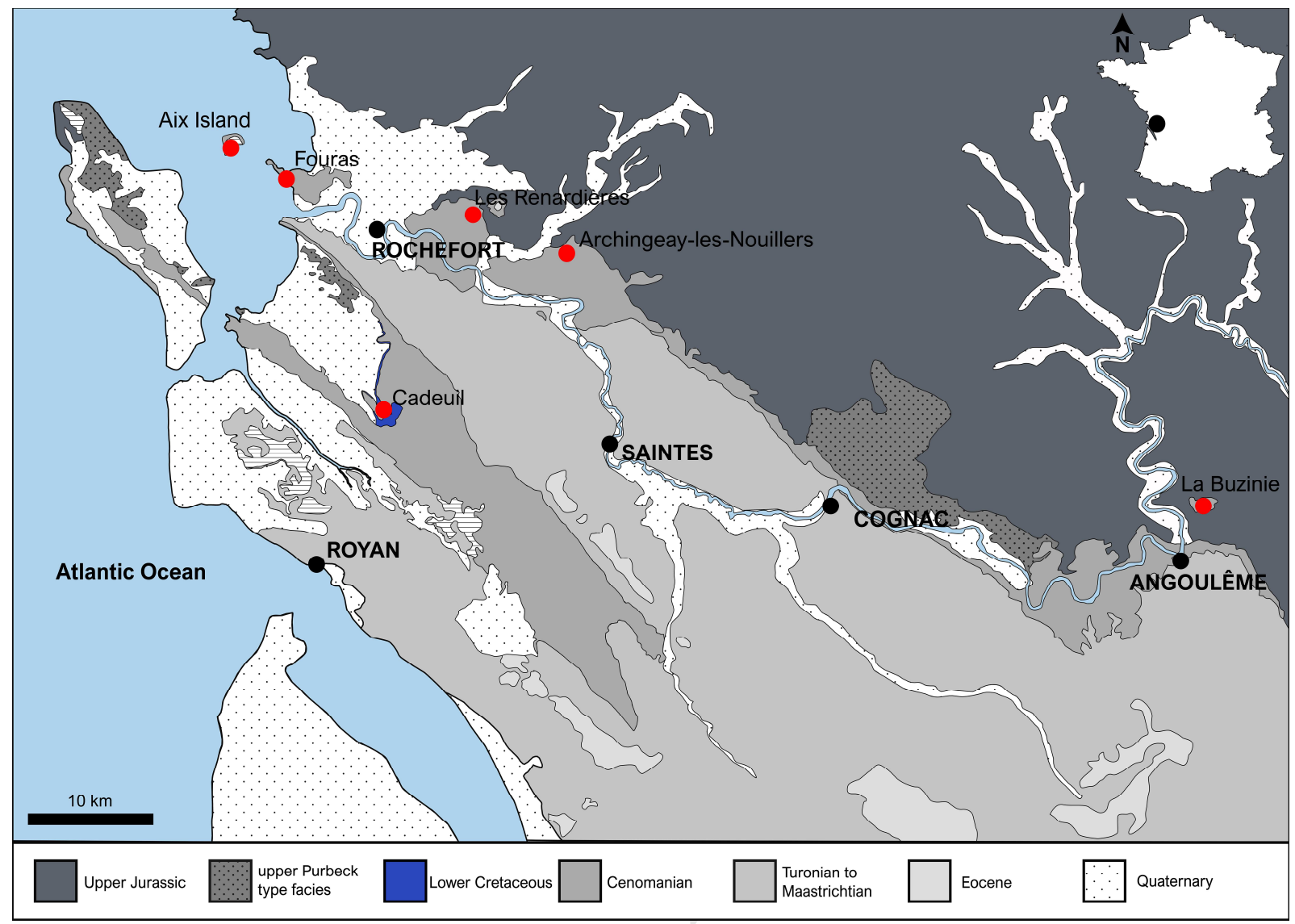



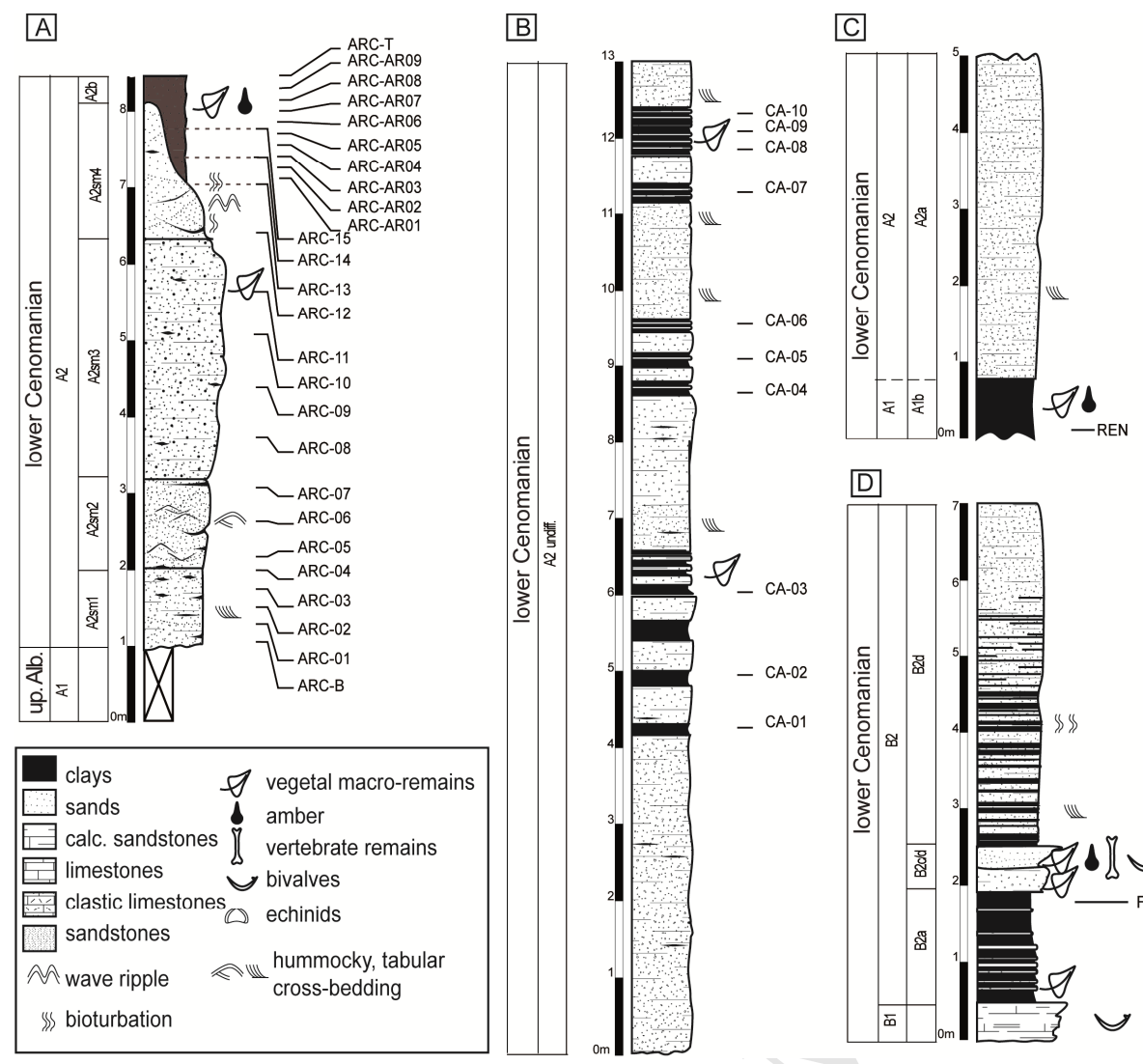

国
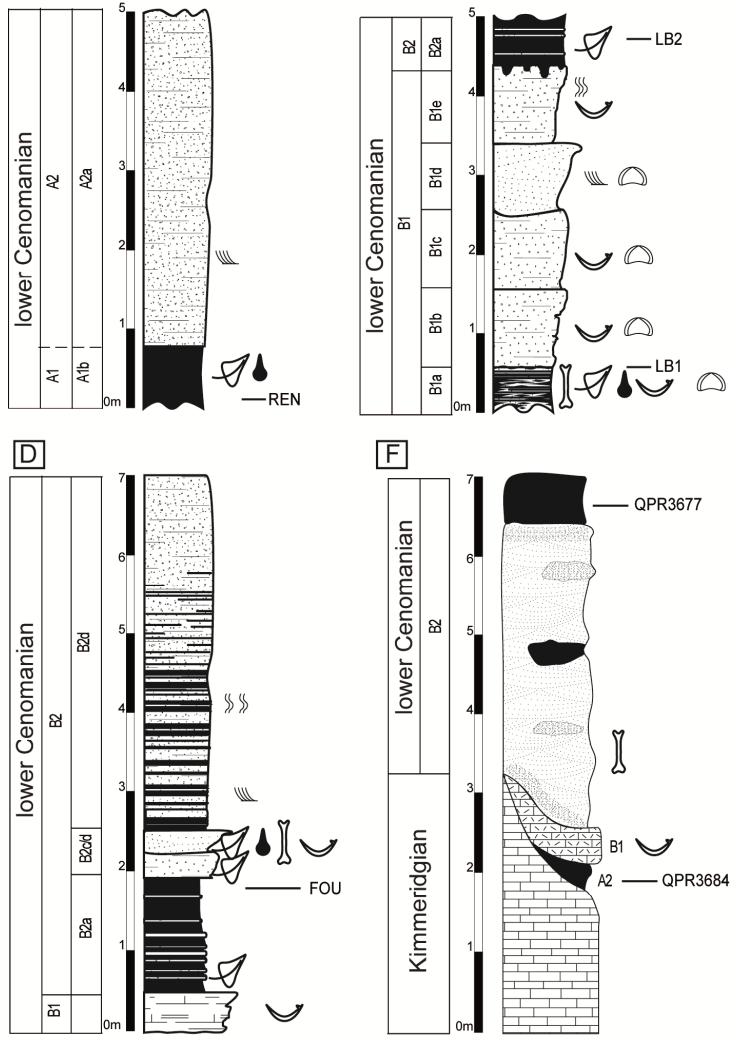

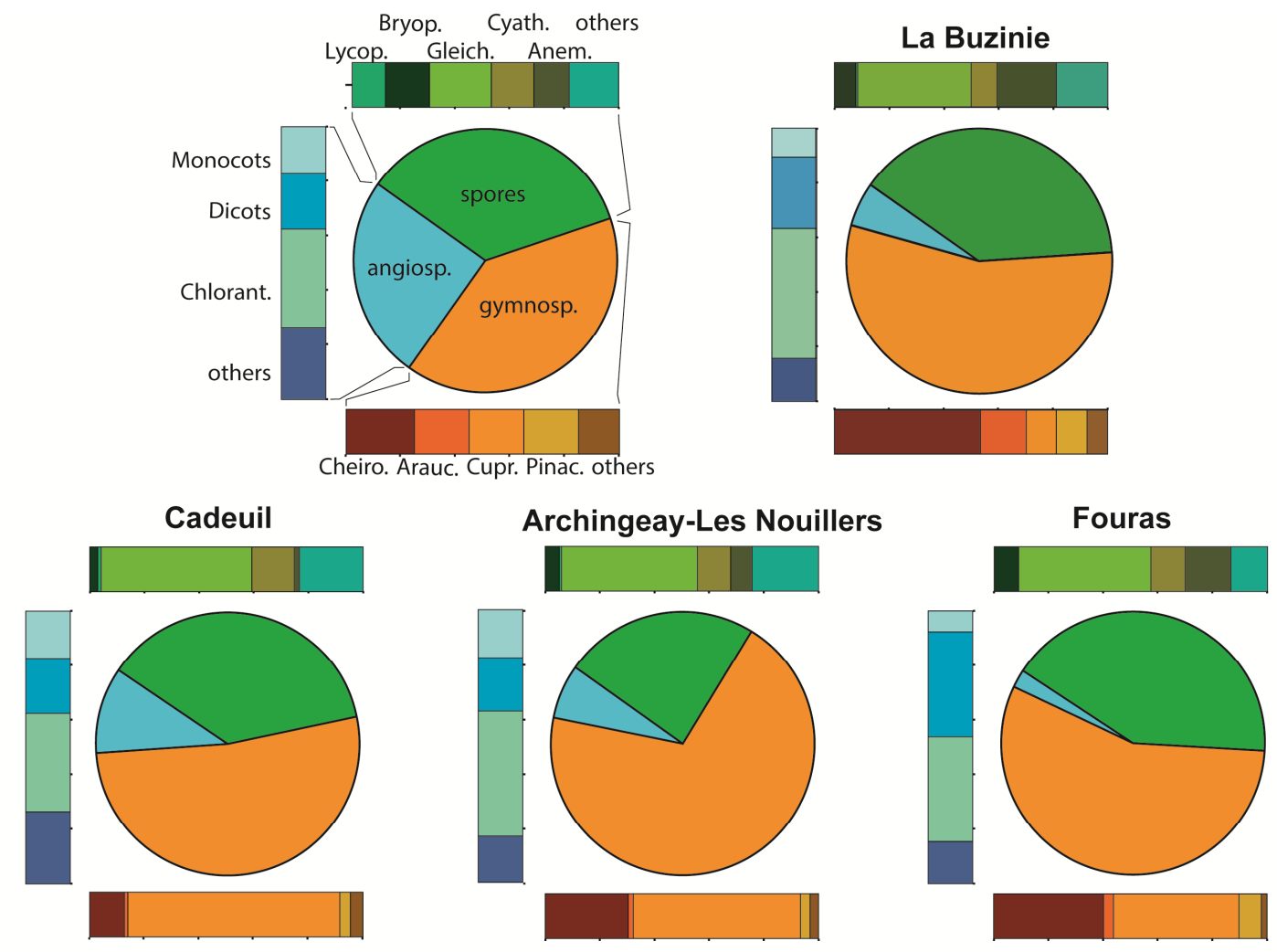

\section{Aix Island Bois-Joli LB1}
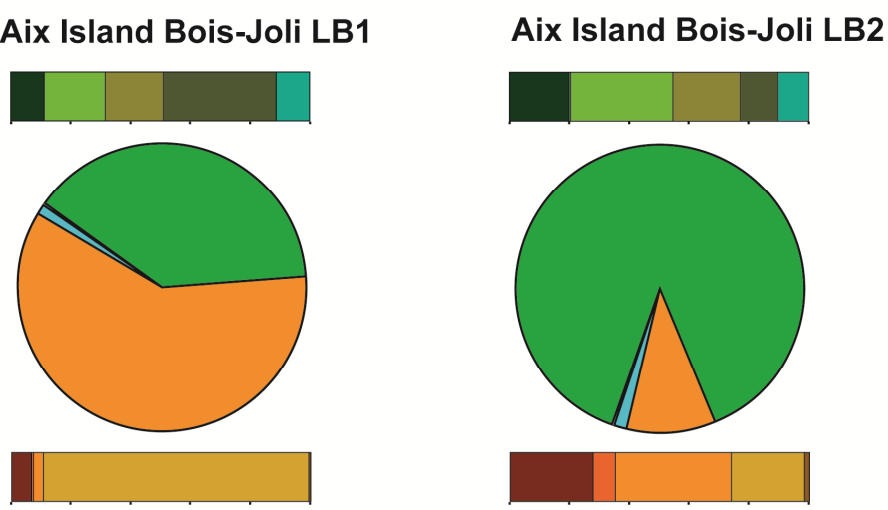

\section{Les Renardieres}
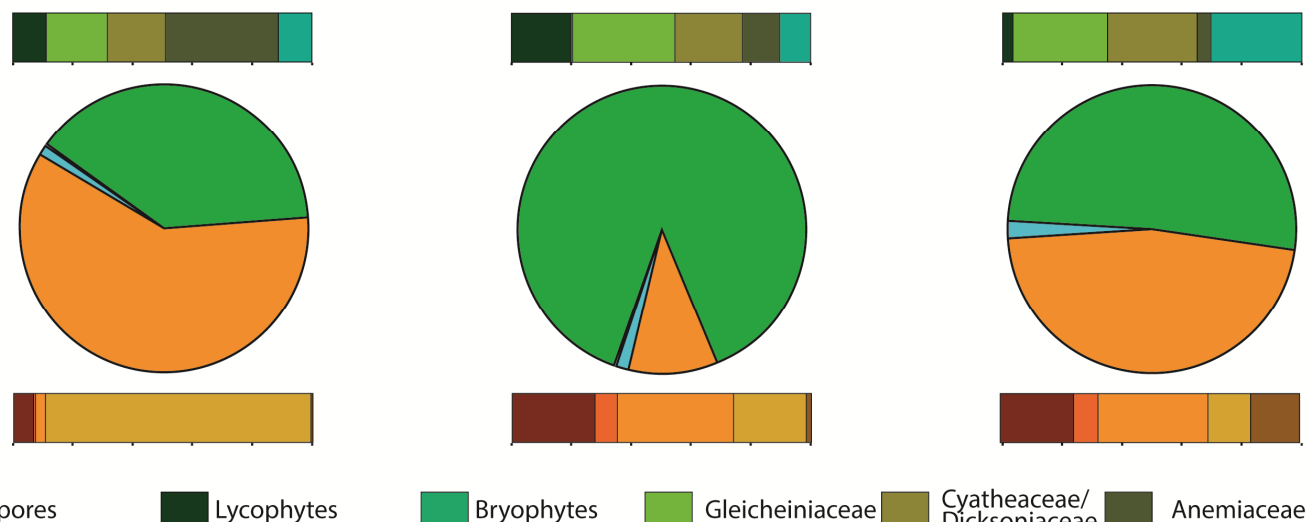

Bryophytes Gleicheiniaceae

Cyatheaceae/
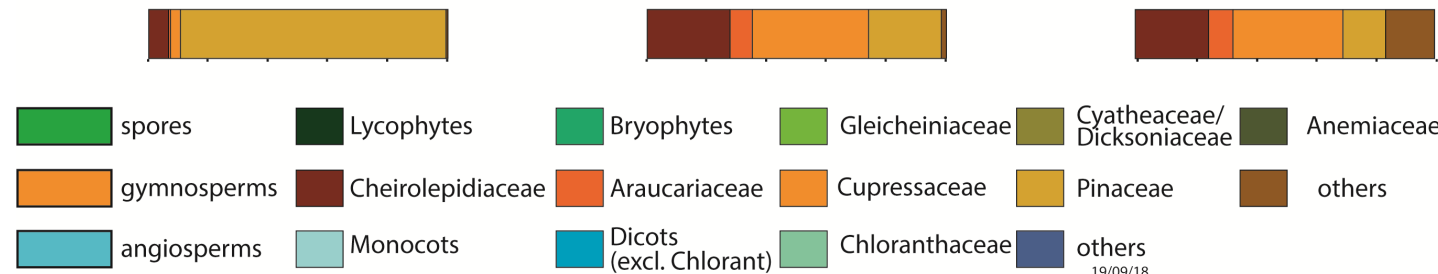

Araucariacea

Cupressaceae

Pinaceae

Anemiaceae

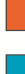

Dicots
(excl. Chlorant)

Chloranthaceae

others 


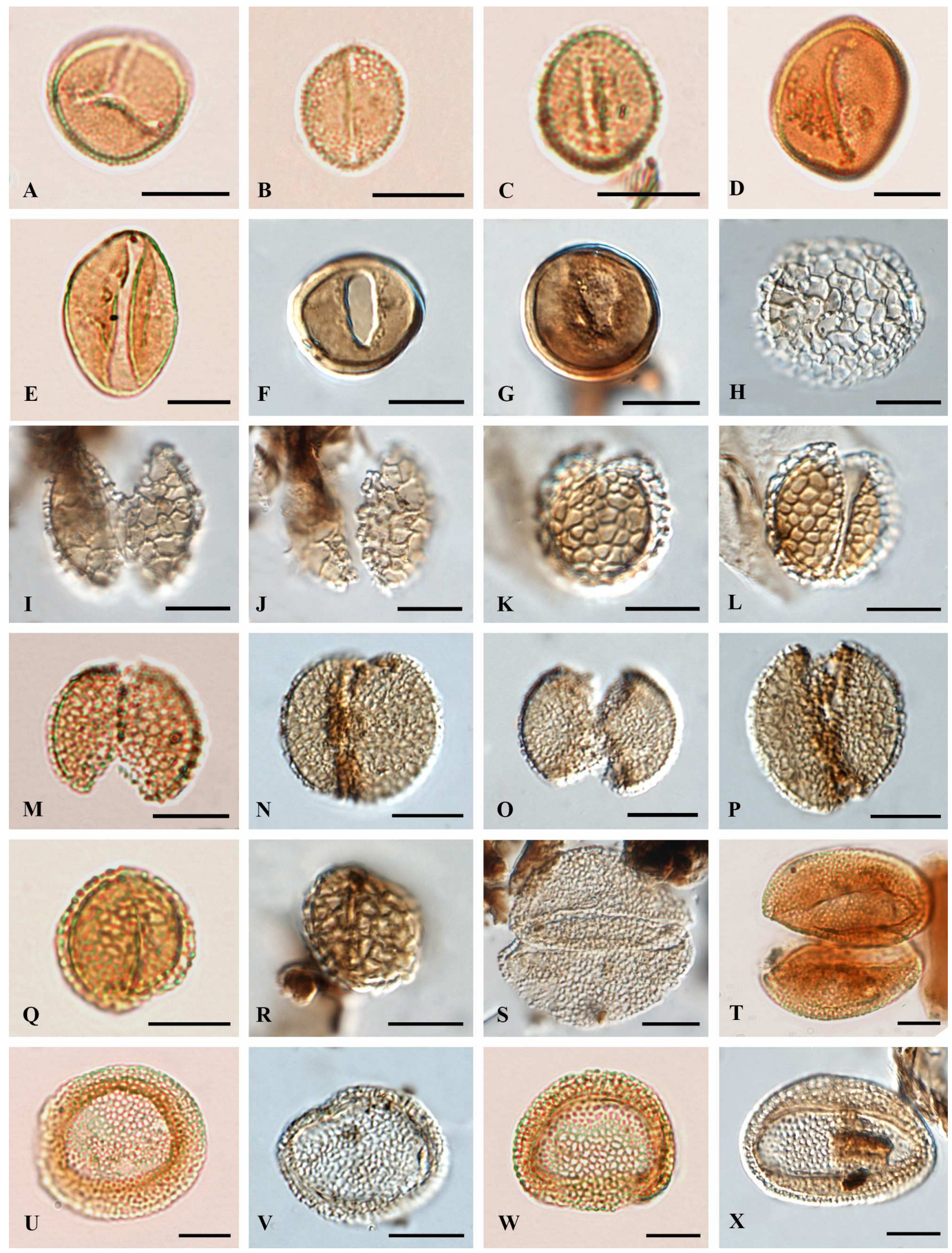




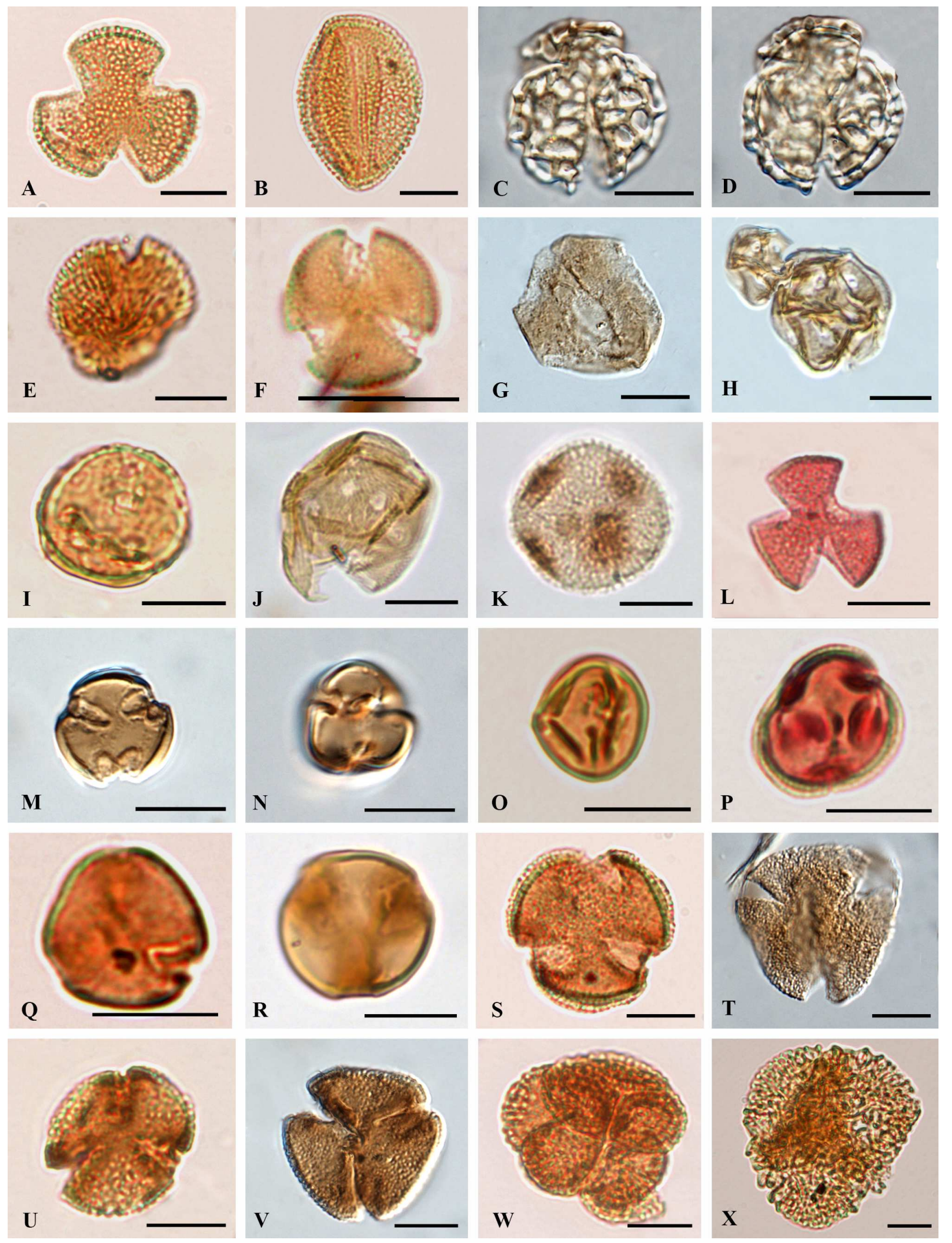



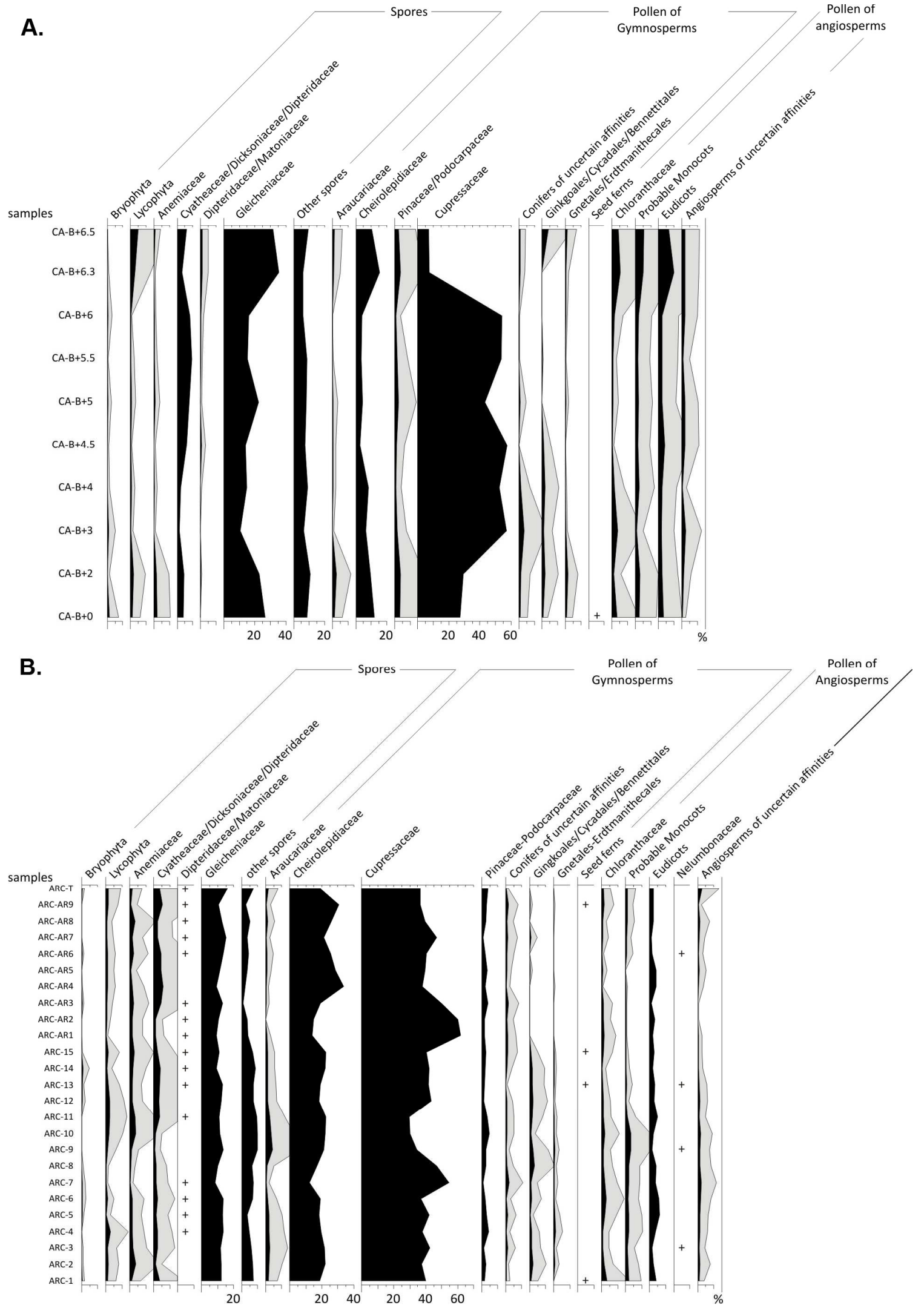

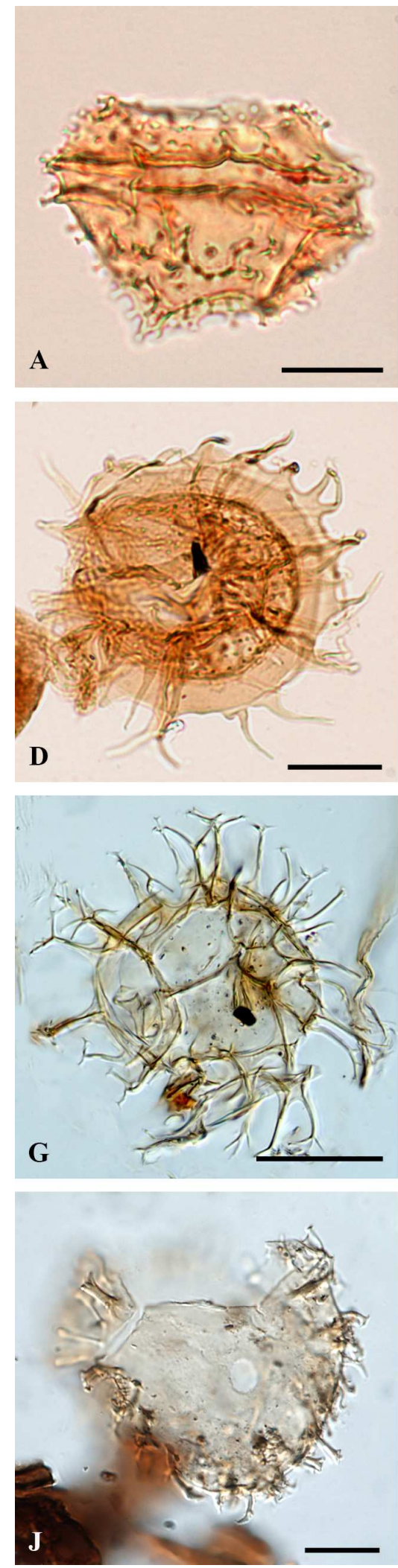
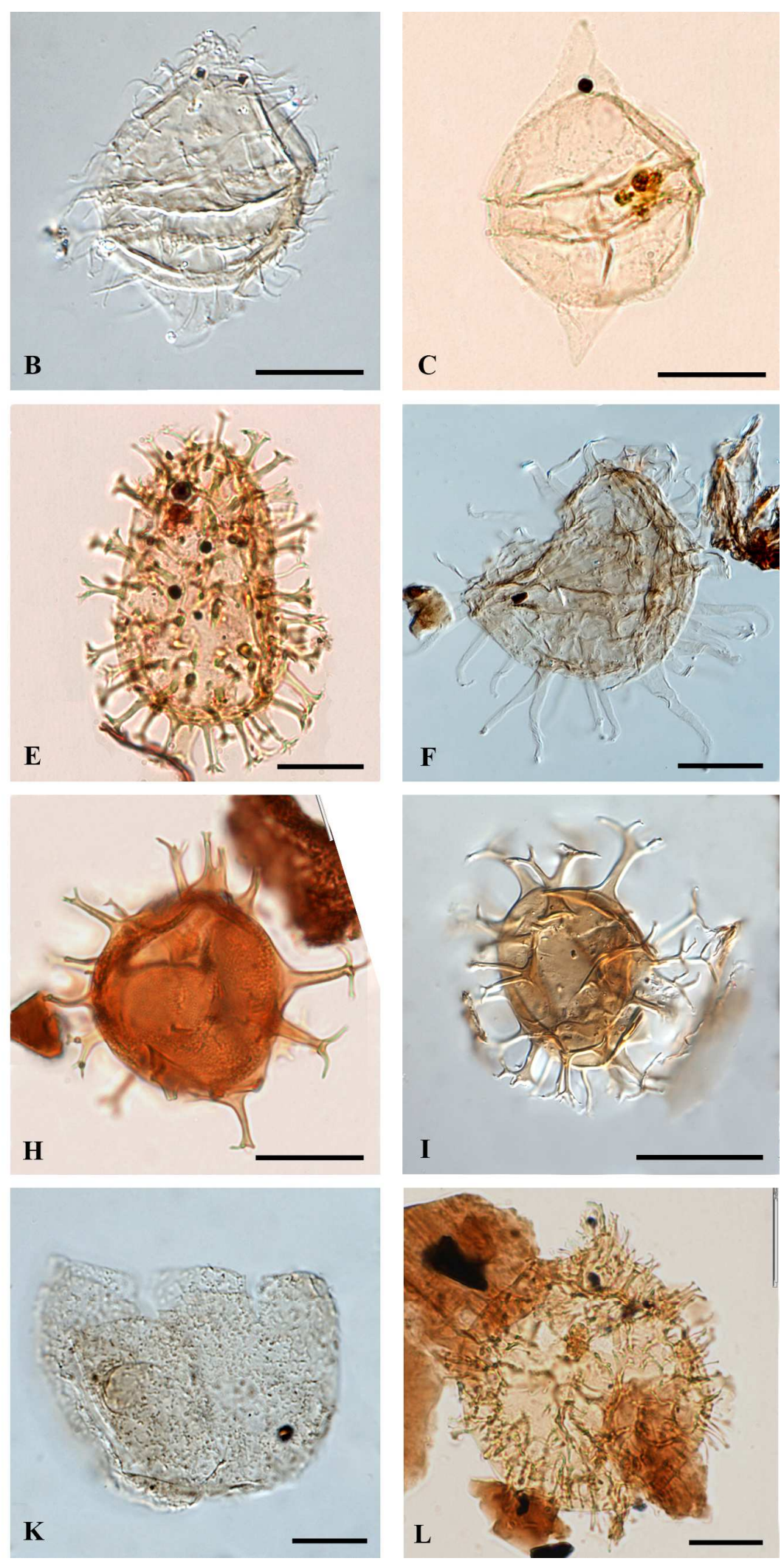

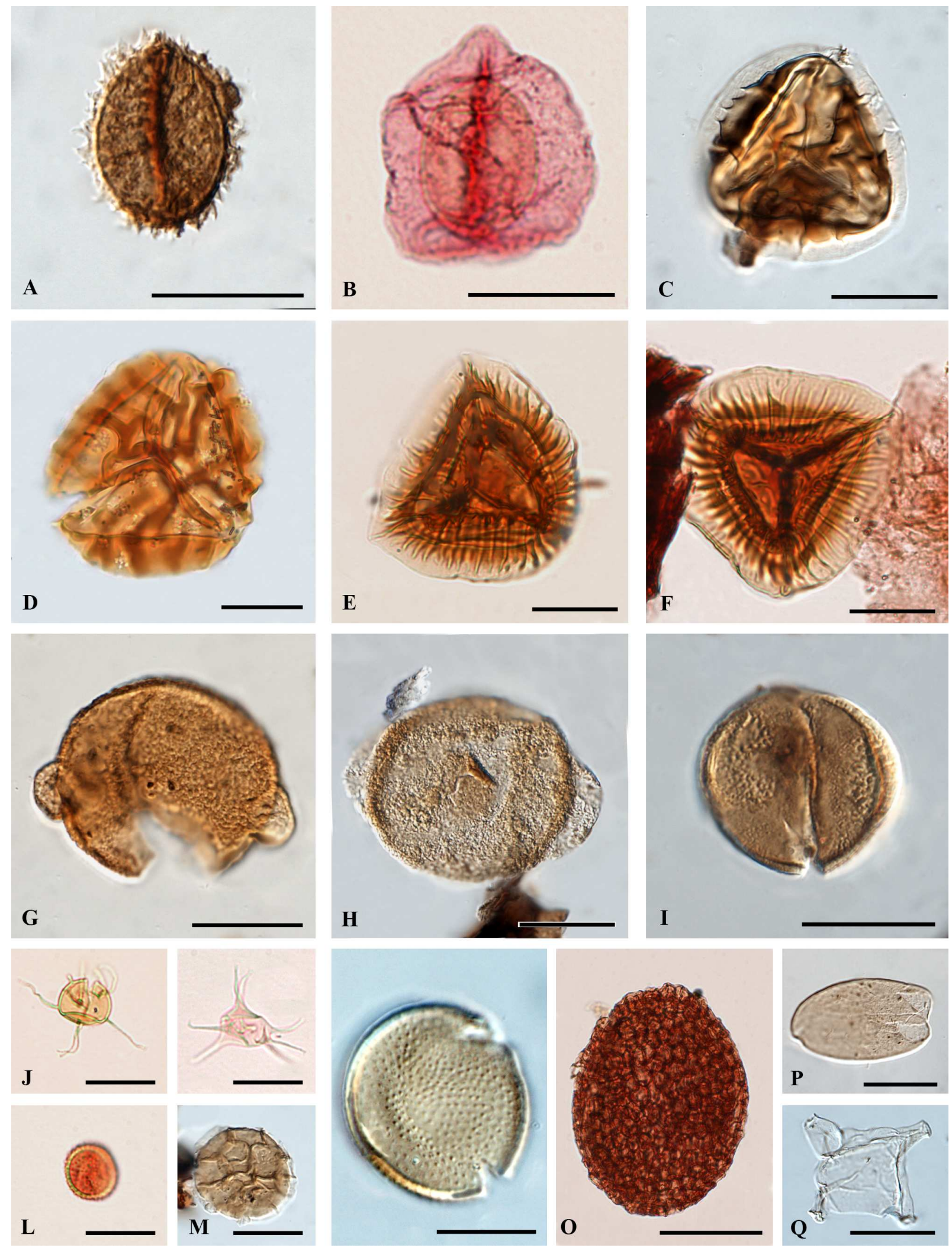

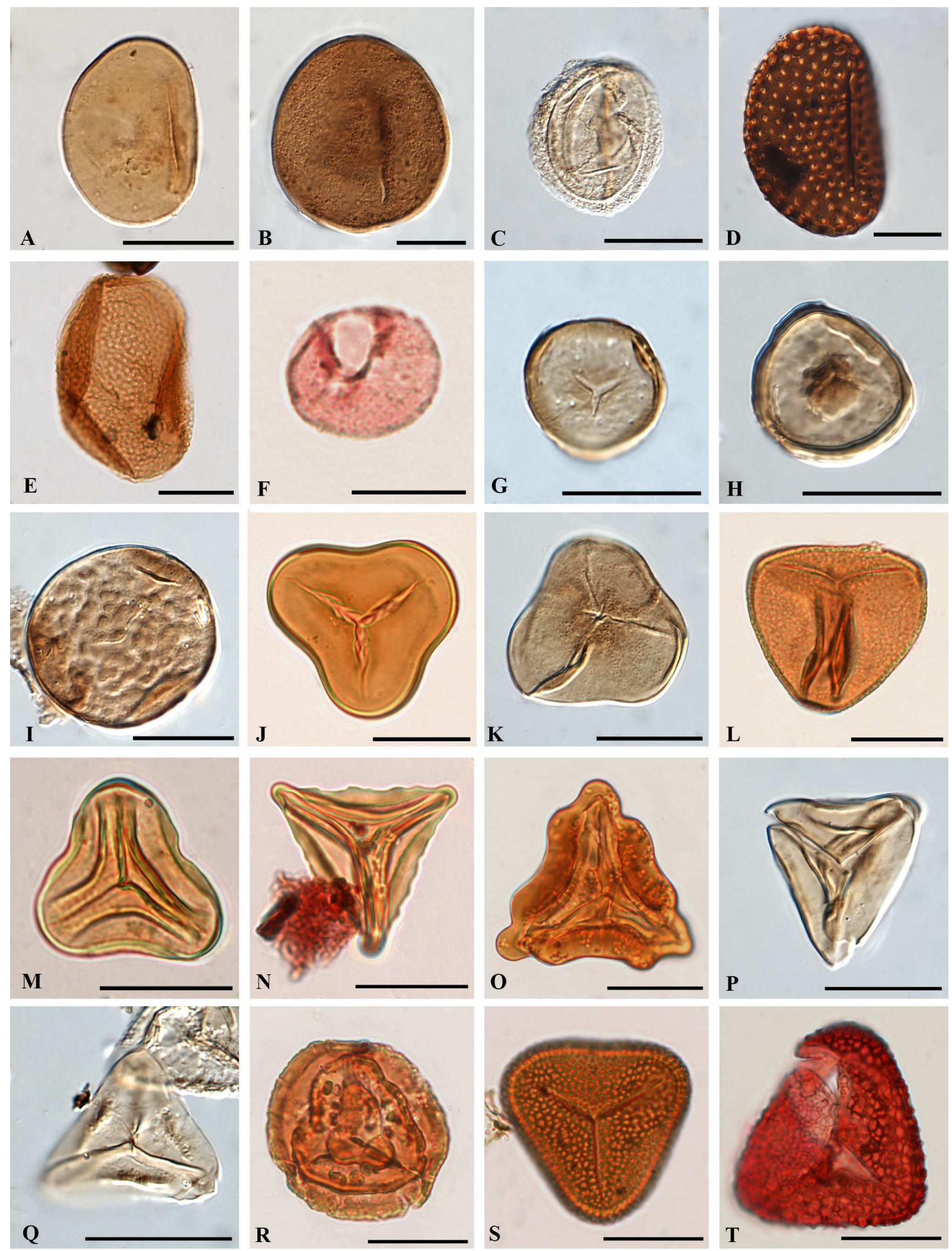

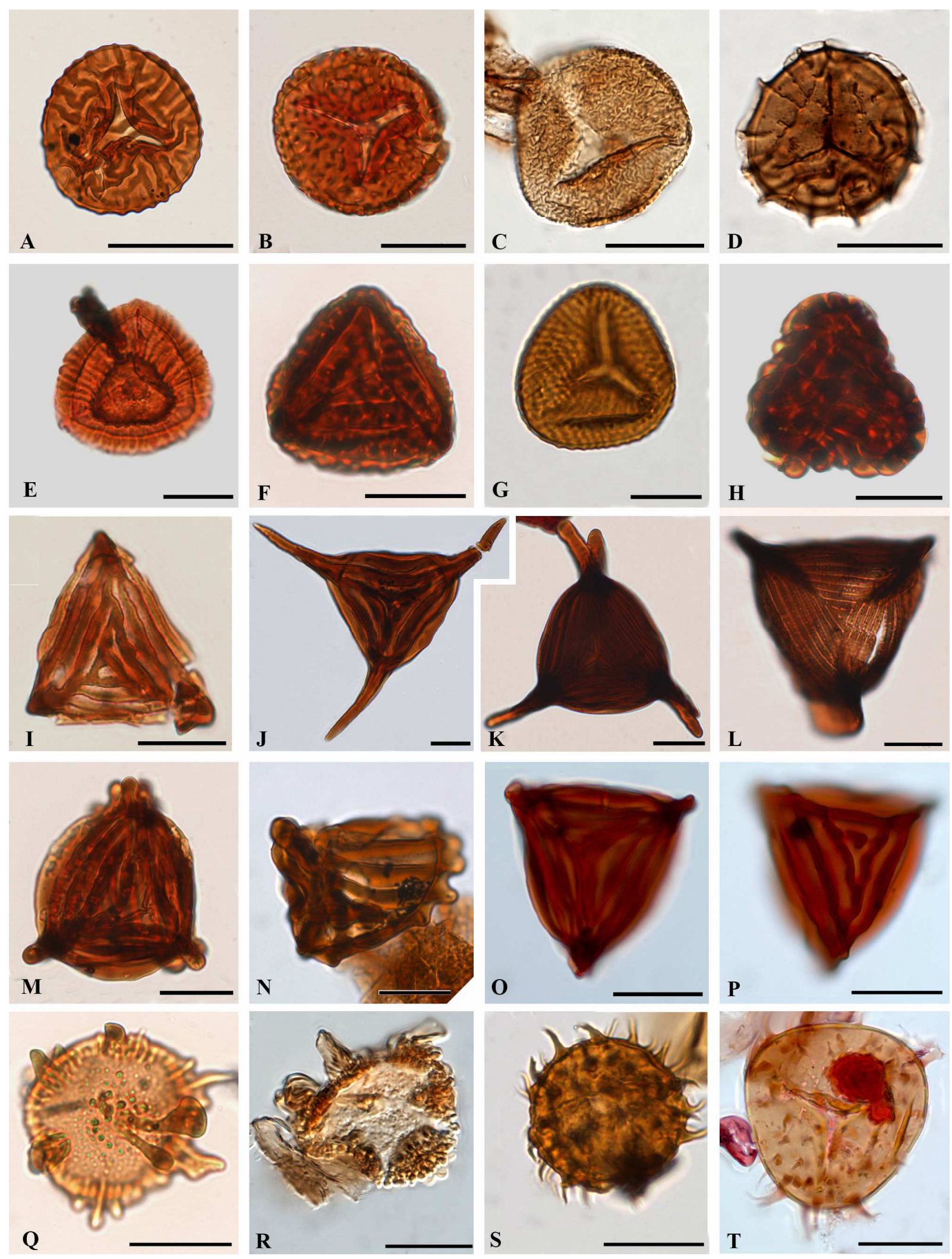

Q
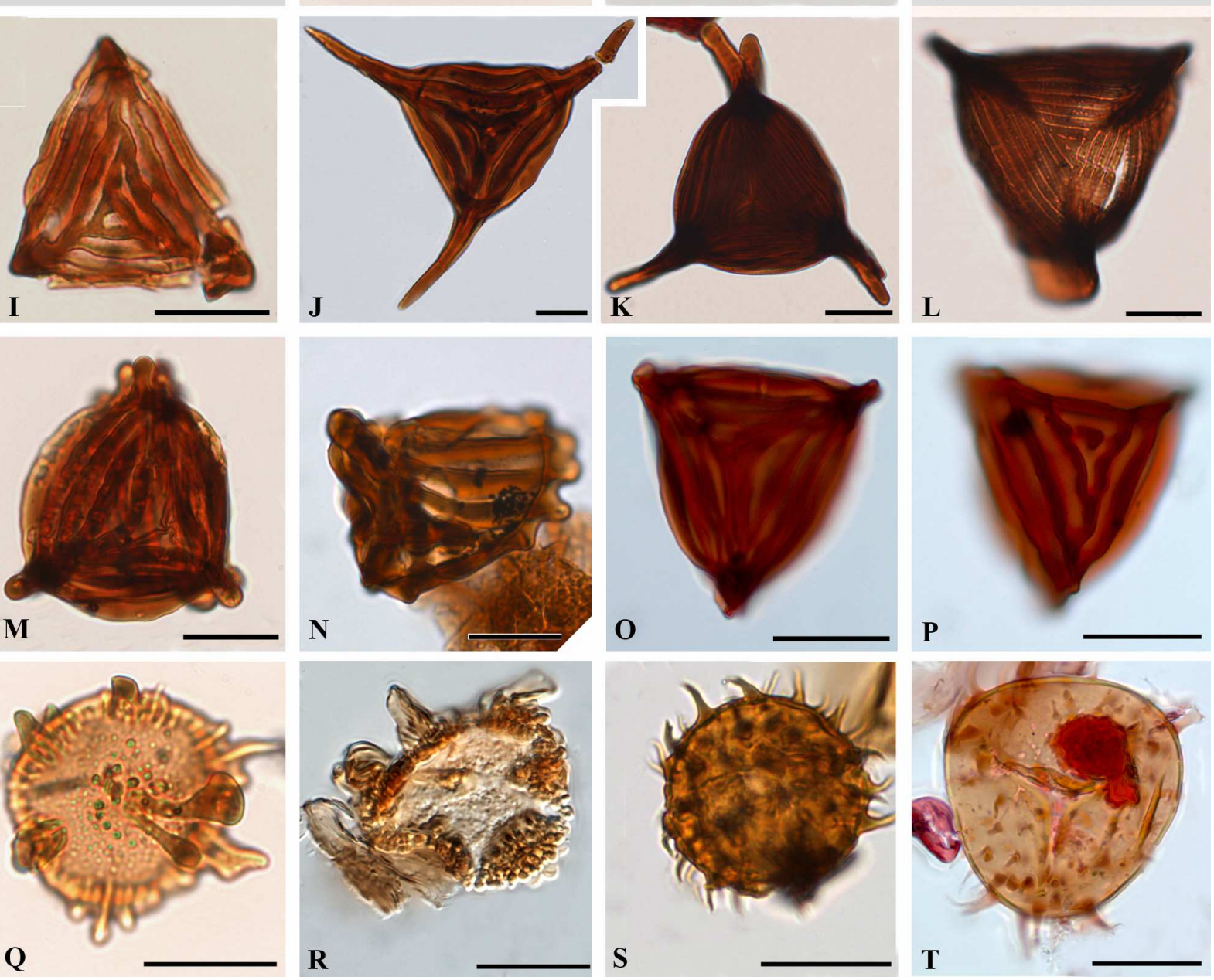


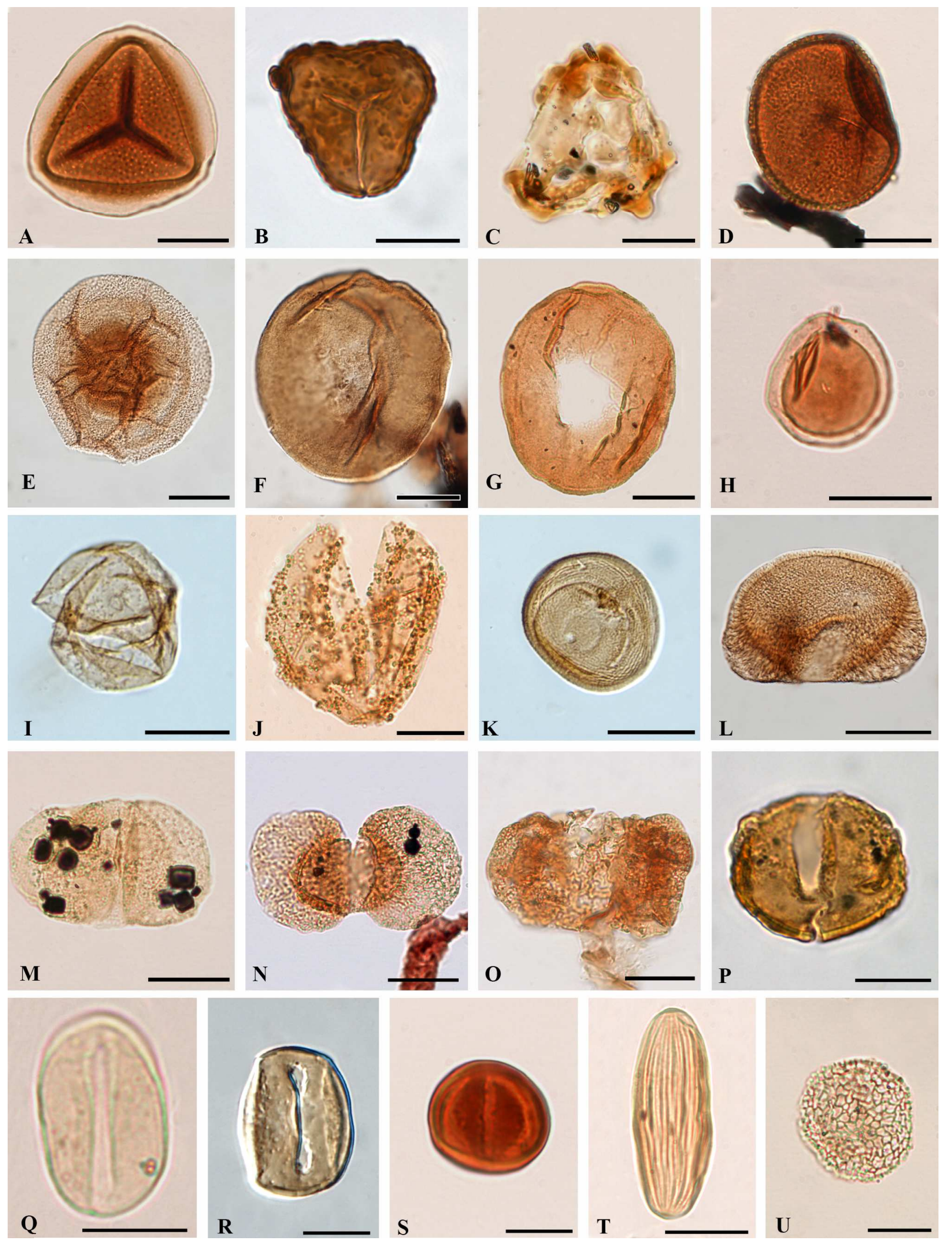

